\title{
36. PHOSPHORUS GEOCHEMISTRY AND ACCUMULATION RATES IN THE EASTERN EQUATORIAL PACIFIC OCEAN: RESULTS FROM LEG $138^{1}$
}

\author{
Gabriel M. Filippelli ${ }^{2}$ and Margaret L. Delaney ${ }^{2}$
}

\begin{abstract}
We determined phosphorus $(\mathrm{P})$ concentrations in Leg 138 sediment samples from Sites 844, 846, and 851, using a sequential extraction technique to identify the $\mathrm{P}$ associated with five sedimentary components. Total concentrations of $\mathrm{P}$ (sum of the five components) ranged from 4 to $35 \mu \mathrm{mol} / \mathrm{P}$ sediment, with mean values relatively similar between the three sites ( 11,14 , and 12 for Sites 844,846 , and 851 , respectively). Authigenic/biogenic $\mathrm{P}$ was the most important component in terms of percentage of total $\mathrm{P}$ (about $75 \%)$, with iron-bound P $(13 \%)$, adsorbed P $(2 \%-9 \%)$, and organic $\mathrm{P}(4 \%)$ of secondary importance; detrital P was a minor P sink (1\%) in these sediments. Profiles of adsorbed $\mathrm{P}$ and iron-bound $\mathrm{P}$ show decreasing concentrations with age, indicating that these components have been affected by diagenesis and reorganization of P. A peak in iron-bound P may reflect higher fluxes of hydrothermally derived Fe to eastern equatorial Pacific Ocean sediments from 11 to $8 \mathrm{Ma}$. Lower detrital P values for western Site 851 reflect a greater distance of this site from a terrigenous source area, compared to that of Sites 844 and 846 .

Phosphorus mass accumulation rates (P-MARs; units of $\mu \mathrm{mol} \mathrm{P} \cdot \mathrm{cm}^{-2} \cdot \mathrm{k} \cdot \mathrm{y}^{-1}$ ) were calculated using total P concentrations (not including the minor and oceanically unreactive detrital $\mathrm{P}$ component) and sedimentation rates and dry-bulk densities averaged over time intervals of 0.5 m.y. P-MARs generally decrease from $17 \mathrm{Ma}$ to the present. Eastern transect Sites 844 and 846 display a decrease in P-MARs from about 30 to 10 in the interval from 17 to $8 \mathrm{Ma}$, while western transect Site 851 is highly variable during this interval. P-MARs increase to about 45 and stay relatively high from 8 to $6 \mathrm{Ma}$, then decrease toward the present to some of the lowest values of the record (about 10). The general trend of high P-MARs at about $6 \mathrm{Ma}$ and decreasing values toward the present is correlated with other geochemical and sedimentary trends through this interval and may reflect (1) a change in net sediment and $\mathrm{P}$ burial, (2) a reorganization of fluxes with no change of net burial, or (3) a combination of the two.
\end{abstract}

\section{INTRODUCTION}

The modern marine phosphorus $(\mathrm{P})$ cycle has been a subject of intense study over the last decade, and the inventories and fluxes of $\mathrm{P}$ in the modern oceanic mass balance have been estimated (Meybeck et al., 1982; Froelich et al., 1982; Froelich, 1984; Mach et al., 1987; Moody et al., 1988; Baturin, 1988; Ruttenberg, 1990). The one significant input source of $\mathrm{P}$ to the oceans is riverine, and the $\mathrm{P}$ flux involved with this input is derived primarily from $P$ released during continental weathering (Fig. 1). The residence time of $\mathrm{P}$ with respect to removal in the modern ocean is about 100,000 $\mathrm{yr}$ (Froelich, 1984), so that feedbacks to $P$ inventories should act to keep input and output fluxes in balance on time scales of the order of 500,000 yr (assuming a steady-state balance for $\mathrm{P}$ in the ocean). Records of oceanic P output fluxes therefore can be used to reconstruct variations in P input fluxes and make inferences about net oceanic productivity.

Continental margin and deep-sea sediments are equally significant for net $\mathrm{P}$ removal (Fig. 1). Determining the history of $\mathrm{P}$ burial in continental margins may be difficult because of local variability in marginal productivity, the strong effects of sea-level change on margin sedimentation, and active sediment reworking and extensive hiatuses in margin sediments. Deep-sea sediments may therefore yield a more complete and unequivocal record of the history of the oceanic P fluxes.

Few studies of $\mathrm{P}$ output fluxes (accumulation rates) have been done through time because of analytical difficulties involved with measuring low deep-sea-sediment P concentrations and stratigraphic uncertainties. Cook (1984) calculated P sedimentation rates in the Indian Ocean (DSDP Legs 22 through 28) from the Jurassic to the present based on $\mathrm{P}$ concentrations in the sediments and estimated sediment accumulation rates (with no corrections for compaction and

' Pisias, N.G., Mayer, L.A., Janecek, T.R., Palmer-Julson, A., and van Andel, T.H. (Eds.), 1995. Proc. ODP Sci. Results, 138: College Station TX (Ocean Drilling Program)

Earth Sciences Department and Institute of Marine Sciences, University of California, Santa Cruz, CA 95064, U.S.A.

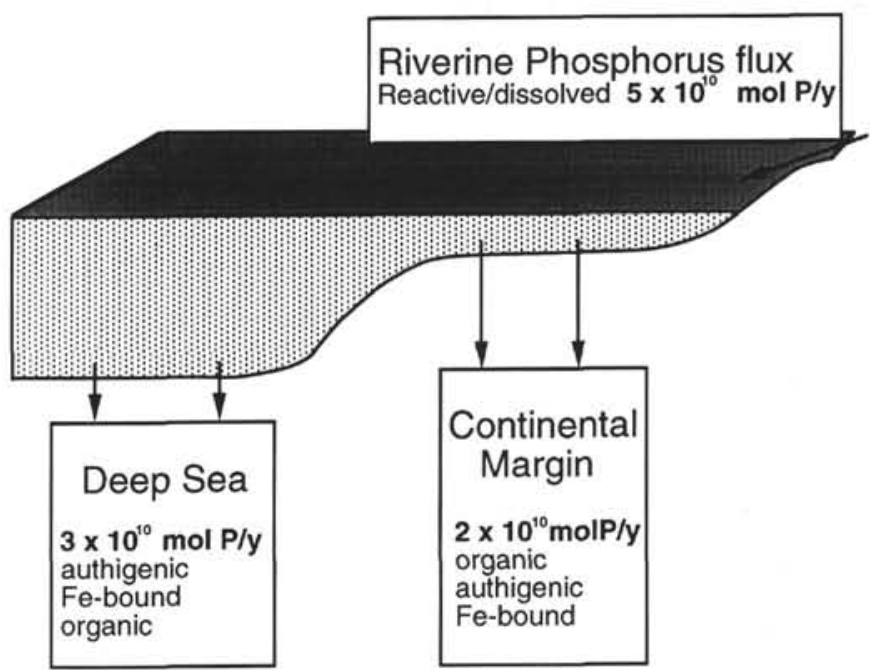

Figure 1. Schematic diagram of $\mathrm{P}$ fluxes and sedimentary forms within the modern marine $\mathrm{P}$ cycle. Fluxes and $\mathrm{P}$ components were compiled from Meybeck et al. (1982), Froelich (1984, 1988), Mach et al. (1987), and Ruttenberg (1990). The $\mathrm{P}$ burial rates are equivalent to mean $\mathrm{P}$ accumulation rates of 10 $\mu \mathrm{mol} P \cdot \mathrm{cm}^{-2} \cdot \mathrm{k} \cdot \mathrm{y}^{-1}$ for deep sea sediments (area of $330 \times 10^{6} \mathrm{~km}^{2}$ ) and 65 $\mu \mathrm{mol} \mathrm{P} \cdot \mathrm{cm}^{-2} \cdot \mathrm{k} \cdot \mathrm{y}^{-1}$ for continental margin sediments (area of $32 \times 106 \mathrm{~km}^{2}$ ). The output fluxes reflect reactive/dissolved output rates; total $\mathrm{P}$ fluxes to the oceans may be three times higher than the reactive flux, and most of this total flux is deposited as detrital (unreactive) forms in continental margin sediments.

sediment density), and found variations in $\mathrm{P}$ accumulation. Moody et al. (1981, 1988) determined $\mathrm{P}$ concentrations and calculated $\mathrm{P}$ accumulation rates over the last $10 \mathrm{Ma}$ for 10 sites in the Pacific ocean and averaged the results for all sites in 1-m.y. intervals. Their results indicated possible peaks in $\mathrm{P}$ accumulation from 5 to 6 and 2 to 3 $\mathrm{Ma}$, though interpretations of oceanic $\mathrm{P}$ accumulation behavior was 
limited by uncertain stratigraphies and large time windows used for averaging. Zhou and Kyte (1992) determined P concentrations and calculated end-member $\mathrm{P}$ component accumulation rates from $85 \mathrm{Ma}$ to the present in pelagic clays from the central South Pacific (DSDP Site 596). Their data showed two broad peaks in end-member $P$ component accumulation rates from about 60 to $45 \mathrm{Ma}$ and about 35 to $20 \mathrm{Ma}$; the record from $20 \mathrm{Ma}$ to the present is marked by hiatuses and low values. They suggested that $P$ associated with carbonate and organic matter is regenerated in the water column above a pelagic clay environment. Furthermore, though presenting no data to support the conjecture, they suggested that their end-member $\mathrm{P}$ component does not record ocean productivity, but rather the accumulation of fish teeth and bone debris.

The eastern equatorial Pacific ocean is a region of sustained high productivity and may be sensitive to changes in Pinput fluxes through time. Ocean Drilling Program Leg 138 has been especially wellsuited for this type of paleoceanographic reconstruction because of record sediment recoveries, fine-scale and continuous stratigraphies, and excellent site-to-site correlations. To further an understanding of $\mathrm{P}$ accumulation in the deep sea, we determined $\mathrm{P}$ concentrations in sediments using a sequential extraction technique (Ruttenberg, 1990; 1992) that isolated five distinct P-bearing sedimentary components. We also calculated $\mathrm{P}$ accumulation rates, based on $\mathrm{P}$ concentrations and sedimentation rates, to elucidate the history of $\mathrm{P}$ output fluxes in this region.

\section{METHODS}

Samples $\left(10 \mathrm{~cm}^{3}\right)$ were taken from Sites 844,846 , and 851 (Table 1). Subsamples (approximately $4 \mathrm{~cm}^{3}$ ) were taken from the bulk samples, dried at $60^{\circ} \mathrm{C}$ to remove moisture, and ground using an acidcleaned porcelain mortar and pestle. To prepare a sample having a limited range of grain sizes for chemical extraction, the ground sample was frequently sieved through an acid-cleaned 120 mesh $(125 \mu \mathrm{m})$ metal sieve. Fine material passing through the sieve was reserved for analysis, and remaining coarser material was ground further. The entire subsample was processed in this manner. We pooled small splits of ground material from each sample we processed from Site 844 (the first site to be studied) to create a large, homogeneous volume of material with a composition typical of our samples, designated a "consistency standard." This was analyzed as a sample with each set of samples processed to monitor analytical reproducibility and to correct determinations for small run to run variability (always less than $10 \%$ of total $\mathrm{P}$ values).

The sequential extraction technique (Ruttenberg 1990, 1992) chemically isolates $\mathrm{P}$ from five sedimentary components, depending on the dissolution characteristics of the components and carefully optimized reagent strengths, acid strengths, reaction order, and reaction times (Table 2). Two 0.5 -g replicates of each ground sample were placed in new $15 \mathrm{~mL}$ polyethylene centrifuge tubes. During each reaction, the centrifuge tubes were shaken on an orbital shaker. $i$ fter each reaction, samples were centrifuged at $4500 \mathrm{rpm}$ for $12 \mathrm{~min}$, and the supernatants were poured from the centrifuged samples into acidcleaned polyethylene collection bottles. Some extraction steps involved multiple treatments, and these supernatants were pooled into one collection bottle for each step. Care was taken throughout the procedure to ensure that laboratory detergen. was not used for cleaning any surfaces with which the samples or reagents came in contact to avoid contamination by $\mathrm{P}$ in the detergents; acid cleaning was used instead $\left(1 \mathrm{~N} \mathrm{HCl}\right.$ at $60^{\circ} \mathrm{C}$ for at least $24 \mathrm{hr}$ ). Glass distilled water was used for reagent preparation and water washes, as well as final rinsing of collection bottles and analysis containers.

For all steps other than iron-bound P, the standard ascorbic acid molybdate blue technique (Strickland and Parsons, 1972) was used for developing color. Sample absorbances and P concentration calculations were performed using a Shimadzu UV-2101PC scanning spectrophotometer with a computer interface and a Sipper 260 autosipper
Table 1. Characteristics of the three Leg 138 sites used in this study.

\begin{tabular}{lccc}
\hline \multicolumn{1}{c}{ Characteristic } & Site & Site & Site \\
& 844 & 844 & 846 \\
\hline Water depth $(\mathrm{m}):$ & 3400 & 3300 & 3800 \\
Latitude $\left({ }^{\circ} \mathrm{N}\right):$ & 7.55 & 3.57 & 2.46 \\
Longitude $\left({ }^{\circ} \mathrm{W}\right):$ & 90.28 & 90.49 & 110.34 \\
Transect: & Eastern & Eastern & Western \\
Age to basement (Ma): & 17 & 18.8 & 12.4 \\
Sediment thickness (mcd): & 310 & 450 & 390 \\
$\mathrm{CaCO}_{3}(\%):$ & $5-70$ & $30-70$ & $70-80$ \\
Sedimentation rate (m/m.y.): & $5-45$ & $10-60$ & $15-55$ \\
Age range of samples used in & $6.8-17$ & $0-18$ & $0-12.4$ \\
this study (Ma): & & & \\
\hline
\end{tabular}

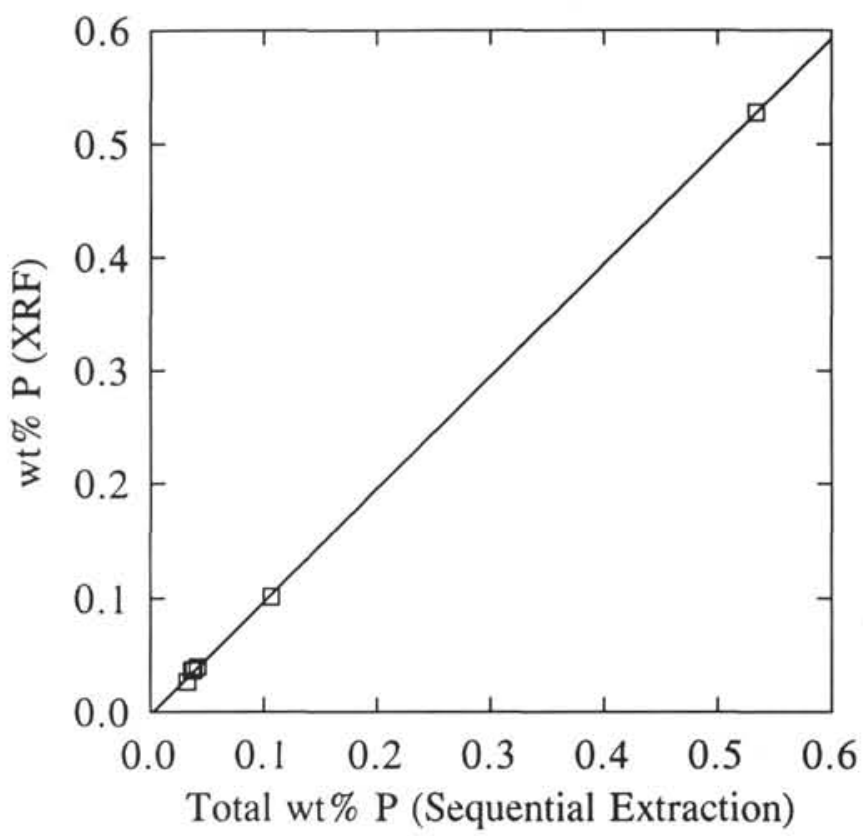

Figure 2. Phosphorus concentrations (wt $\% \mathrm{P}$ ) in six selected samples from Site 846 as determined by $\mathrm{X}$-ray fluorescence vs. total of the sequential extraction results used in this study. XRF determinations were performed on a Philips PW1410 X-ray spectrometer with a $\mathrm{Cr}$ tube and a Cu sample mask after fusion of sample powder with lithium tetraborate/metaborate flux into a glass disk. Standards having P concentrations near those of these samples were used, and typical reproducibility of multiple determinations was $\pm 5 \%$. Analytical errors on Pdeterminations for each technique are within the width of the symbol. The correlation coefficient, $r^{2}$, is 0.999 and the slope is 0.992 . The mean $\mathrm{P}$ concentration value for all Site 846 samples is equivalent to $0.049 \mathrm{wt} \%$, with a range of 0.027 to $0.11 \mathrm{wt} \%$ for all samples but the basal sample $(0.54 \mathrm{wt} \%$ ), Excluding the basal sample from the regression calculations, $r^{2}=0.995$ and the slope is 0.975 .

attachment to introduce samples to the 1-cm fixed quartz analysis cell. Sample absorbances were zeroed vs. water and measured at $885 \mathrm{~nm}$ with a slit width of $5 \mathrm{~nm}$. Reagent blanks and standards were prepared to match the matrix of each sample step analyzed. Samples were undiluted for adsorbed $\mathrm{P}$, diluted 10:1 for authigenic/biogenic $\mathrm{P}$, and diluted 5:1 for detrital and organic P determinations. The presence of the citrate-dithionite buffer used for Fe-bound $\mathrm{P}$ interferes with the reduction of the molybdate-P complex, and therefore an organic extraction of the complex into isobutanol was used to remove the interfering complex (Watanabe and Olsen, 1962; Ruttenberg, 1992). The extracted complex was reduced with $\mathrm{SnCl}_{2}$, diluted with ethanol, and the absorbance of the colored solution was measured at $730 \mathrm{~nm}$ (with a slit width of $5 \mathrm{~cm}$ and a $1 \mathrm{~cm}$ quartz cell).

Sequential extraction techniques are useful for elucidating associations of elements having individual sedimentary components and 
Table 2. Sequential extraction technique description (after Ruttenberg, 1992).

\begin{tabular}{|c|c|c|c|c|}
\hline $\begin{array}{l}\text { Step } \\
\text { name }\end{array}$ & $\begin{array}{l}\text { Step } \\
\text { no. }\end{array}$ & $\begin{array}{l}\text { Sequential } \\
\text { treatments }\end{array}$ & Reaction process & $\begin{array}{l}\mathrm{P} \text { component } \\
\text { isolated }\end{array}$ \\
\hline Adsorbed & I & $\begin{array}{l}10 \mathrm{~mL} 1 \mathrm{M} \mathrm{MgCl}_{2}(2 \mathrm{~h}) \\
10 \mathrm{~mL} \mathrm{H}_{2} \mathrm{O}(2 \mathrm{~h}) \\
10 \mathrm{~mL} \mathrm{H}_{2} \mathrm{O}(2 \mathrm{~h})\end{array}$ & $\begin{array}{l}\text { Formation of } \mathrm{MgPO}_{4} \text { - complex } \\
\text { and/or mass action displacement } \\
\text { by } \mathrm{Cl}^{-} ; \mathrm{H}_{2} \mathrm{O} \text { displaces reagent for } \\
\text { following step }\end{array}$ & Exchangeable or loosely sorbed $\mathrm{P}$ \\
\hline Fe-bound & II & $\begin{array}{l}10 \mathrm{~mL} \mathrm{CDB} \text { solution }(6 \mathrm{~h}) \\
\left(0.22 \mathrm{M} \mathrm{Na}_{3} \text {-citrate, } 0.11 \mathrm{M}\right. \\
\mathrm{NaHCO}_{3}, 0.13 \mathrm{M} \text { Na-dithionite, } \\
\text { as } 0.225 \mathrm{~g} \text { powder }) \\
10 \mathrm{~mL} \mathrm{I} \mathrm{M} \mathrm{MgCl}_{2}(2 \mathrm{~h}) 10 \mathrm{~mL} \\
\mathrm{H}_{2} \mathrm{O}(2 \mathrm{~h})\end{array}$ & $\begin{array}{l}\text { Reduction of } \mathrm{Fe}^{3+} \text { by dithionite and } \\
\text { subsequent chelation by citrate }\end{array}$ & Reducible or reactive Fe-bound $\mathrm{P}$ \\
\hline Authigenic/ biogenic & III & $\begin{array}{l}10 \mathrm{~mL} \text { IM Na-acetate buffered } \\
\text { to } \mathrm{pH} 4 \text { w/acetic acid }(5 \mathrm{~h}) 10 \mathrm{~mL} \\
1 \mathrm{M} \mathrm{MgCl} 2(2 \mathrm{~h}) 10 \mathrm{~mL} 1 \mathrm{M} \mathrm{MgCl}_{2} \\
\text { (2h) } 10 \mathrm{~mL} \mathrm{H}_{2} \mathrm{O}(2 \mathrm{~h})\end{array}$ & Acid dissolution at a low $\mathrm{pH}$ & $\begin{array}{l}\text { Carbonate fluor-apatite (CFA), } \\
\text { biogenic hydroxy-apatite, and } \\
\mathrm{CaCO}_{3} \text {-bound } \mathrm{P}\end{array}$ \\
\hline Detrital & IV & $13 \mathrm{~mL} 1 \mathrm{~N} \mathrm{HCl}(16 \mathrm{~h})$ & Acid dissolution at a very low $\mathrm{pH}$ & Detrital fluor-apatite-bound P \\
\hline Organic & V & $\begin{array}{l}1 \mathrm{~mL} 50 \%(\text { w/v }) \mathrm{MgCl}_{2}, \text { dry } \\
\text { in low oven, ash at } 550^{\circ} \mathrm{C} \\
13 \mathrm{~mL} 1 \mathrm{~N} \mathrm{HCl}(24 \mathrm{~h})\end{array}$ & $\begin{array}{l}\text { Dry oxidation of organics; acid } \\
\text { dissolution of ashed residue at a } \\
\text { very low } \mathrm{pH}\end{array}$ & Organic P \\
\hline
\end{tabular}

${ }^{a}$ Also the reaction process for iron-bound $\mathrm{P}$ and authigenic/biogenic $\mathrm{P}$ treatments.

for yielding more chemical information than bulk determinations. However, these techniques have been criticized because the components that they differentiate are operationally defined and are not necessarily discrete chemical or sedimentary entities definable by other methods (see Nirel and Morel, 1991, for discussion). We compared total $\mathrm{P}$ concentrations (the sum of $\mathrm{P}$ concentrations in individual components) determined by this technique with $\mathrm{P}$ concentration results from X-ray fluorescence, using selected samples from Site 846 and our consistency standard for the comparison. Although concentrations associated with individual components are operationally defined and not directly testable by other techniques, total $\mathrm{P}$ values reported here are comparable to those determined by the widely used XRF technique with no apparent offset (Fig. 2). We also have interpreted sequential extraction component results presented here with an understanding of the chemical processes involved in isolating the components and of the composition of the samples compared to the composition of the material for which the technique was optimized.

Phosphorus accumulation rate (reported throughout as $\mu \mathrm{mol}$ $\left.\mathrm{P} \cdot \mathrm{cm}^{-2} \cdot \mathrm{k} \cdot \mathrm{y}^{-1}\right)$ for each sample was calculated using the P concentration $(\mu \mathrm{mol} \mathrm{P} / \mathrm{g}$ sediment), the mean sedimentation rate $(\mathrm{m} / \mathrm{m}$.y.; mean of 0.5 -m.y. intervals), and the mean dry bulk-density $\left(\mathrm{g} / \mathrm{cm}^{3} ;\right.$ mean of the same 0.5 -m.y. intervals). Mean sedimentation rates over the 0.5 m.y. intervals are presented in Shackleton et al. (this volume). Mean dry-bulk densities are calculated from values given in individual Leg 138 Site chapters (Mayer, Pisias, Janecek, et al., 1992).

P-MARs were not calculated for individual components because they are influenced by diagenesis, and we found reorganization of $\mathrm{P}$ between these components with age (as we discuss later). Accumulation rates for $\mathrm{P}$ in individual components reflect a combination of original deposition and diagenetic redistribution. By using the sum of the components, we do not need to consider reorganization of $\mathrm{P}$ between sinks and can instead focus on the total flux of $\mathrm{P}$ that is buried.

\section{RESULTS AND DISCUSSION}

\section{Phosphorus Concentrations}

Phosphorus concentrations for the five sedimentary components and total P concentration (as the sum of all components) are presented in Tables A1 through A3. Sample ages were determined by sample composite depth (mcd) and age models of Shackleton et al. (this volume) based on orbitally tuned ages from GRAPE records and correlation to Cande and Kent (1992). Sample 138-846B-45X-1, $50-52 \mathrm{~cm}$ (Table A2) is a metalliferous basal sediment, not typical of other samples analyzed. Compared to others, the elevated P concentrations of this sample are interesting as an example of P scavenging by metalliferous sediments (Froelich et al., 1977), but they are not included in the following discussions.

Representative analytical figures of merit and mean P concentrations for each P-bearing component are presented in Table 3 for all three sites. Though total P concentrations ranged from 4 to $35 \mu \mathrm{mol}$ $\mathrm{P} / \mathrm{g}$ sediment (Tables $\mathrm{A} 1-\mathrm{A} 3$ ), mean $\mathrm{P}$ concentrations are relatively similar between the three sites $(11,14$, and 12 for Sites 844,846 , and 851 , respectively; Table 3 ). An order of magnitude range in P concentrations exists between the five sedimentary components (Table 3 ). However, the five sedimentary components constitute remarkably similar percentages of total $\mathrm{P}$ in the three sites (Fig. 3). The most important $\mathrm{P}$ component is authigenic/biogenic $\mathrm{P}$, which accounts for about $75 \%$ of total P. Of secondary importance are Fe-bound $\mathrm{P}(13 \%)$, adsorbed P (2\%-9\%), and organic P (4\%). Detrital P is a minor P component $(1 \%)$. These percentages of the various components therefore represent the post-deposition P composition of typical deep sea sediments in this oceanographic setting. Estimates of the P flux to sediments indicate that most of the total P flux is organically-bound (Froelich et al., 1982; Ruttenberg, 1990; Ruttenberg and Berner, 1993). Because organic $P$ is a relatively minor portion of total $P$ in our samples (about 4\%; Fig. 3), P associated with this component must either be redistributed or lost out of the sediments during organic matter remineralization and sediment burial. The high $\mathrm{P}$ concentrations observed in these sediments indicate that most of this P is retained, which argues for redistribution of $\mathrm{P}$ from organically bound to other forms with increasing sediment age.

\section{Adsorbed $P$}

Concentrations of adsorbed P, adsorbed or loosely sorbed onto grain surfaces, range from about 0.2 to $2 \mu \mathrm{mol} \mathrm{P} / \mathrm{g}$ sediment $(0.0006$ to $0.006 \mathrm{wt} \% \mathrm{P}$; Fig. 4A). A clear decrease in P concentration is seen with age, with the greatest decrease from 0 to about $10 \mathrm{Ma}$ (Fig. 4A), which is especially evident in Site 846 and Site 851 samples covering this age range. Adsorbed $\mathrm{P}$ values are comparable where determinations for the different sites overlap, indicating that initial and postdiagenesis pore water $\mathrm{P}$ concentrations are relatively constant between these sites.

The decrease in adsorbed $\mathrm{P}$ with sample age is linked to exchange with interstitial water phosphate. Though too low to be detectable with shipboard methods, interstitial water phosphate concentrations 
Table 3. Analytical figures of merit for determining concentrations of $\mathbf{P}$.

\begin{tabular}{|c|c|c|c|c|c|c|}
\hline \multirow[b]{2}{*}{ Site } & \multicolumn{5}{|c|}{ Sequential extraction component } & \multirow[b]{2}{*}{ Total } \\
\hline & Adsorbed & $\begin{array}{l}\text { Iron- } \\
\text { bound }\end{array}$ & $\begin{array}{c}\text { Auth./ } \\
\text { biogenic }\end{array}$ & Detrital & Organic & \\
\hline \multicolumn{7}{|l|}{ 138-844B (34 samples) } \\
\hline Mean $[\mathrm{P}]^{a}$ & 0.306 & 1.32 & 8.88 & 0.085 & 0.45 & 11.0 \\
\hline Mean s.d. ${ }^{b}$ & 0.032 & 0.22 & 0.70 & 0.013 & 0.17 & 0.9 \\
\hline Mean \% error ${ }^{c}$ & 10.8 & 24.2 & 8.0 & 27.9 & 57.1 & 8.4 \\
\hline \multicolumn{7}{|l|}{ 138-846B (45 samples) } \\
\hline Mean $[\mathrm{P}]$ & 0.667 & 2.23 & 10.12 & 0.139 & 0.91 & 14.1 \\
\hline Mean s.d. & 0.024 & 0.20 & 0.38 & 0.036 & 0.10 & 0.5 \\
\hline Mean \% error & 3.0 & 11.3 & 4.3 & 23.8 & 26.1 & 5.2 \\
\hline \multicolumn{7}{|l|}{ 138-851 B (68 samples) } \\
\hline Mean $[\mathrm{P}]$ & 1.04 & 1.41 & 8.31 & 0.083 & 0.62 & 11.5 \\
\hline Mean s.d. & 0.016 & 0.14 & 0.85 & 0.015 & 0.14 & 0.9 \\
\hline Mean \% error & 1.8 & 12.4 & 11.8 & 22.6 & 23.9 & 8.6 \\
\hline Typical detection limit ${ }^{d}$ & 0.057 & 0.03 & 0.08 & 0.033 & 0.11 & \\
\hline
\end{tabular}

${ }^{a}$ Mean P concentration of all samples for each component (in mol P/g sediment)

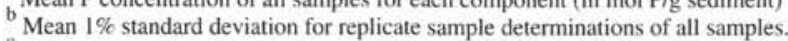

c Mean error percentage calculated as the mean of error percentage values for individual sample determinations.

${ }^{d}$ Typical detection limit defined as 3 times the standard deviation of a reagent blank for the colorimetric determination of $\mathrm{P}$ concentrations for each component.

are expected to decrease with age due to decreasing source (reactive organic matter) and incorporation of interstitial dissolved phosphate into authigenic minerals. The adsorbed $\mathrm{P}$ profile indicates that this process continues to about $10 \mathrm{Ma}$ or depths of tens to hundreds of meters.

\section{Iron-bound $P$}

Concentrations of iron-bound $\mathrm{P}$, associated with easily reducible iron oxides and/or oxyhydroxides, generally range from 0.5 to $3 \mu \mathrm{mol}$ $\mathrm{P} / \mathrm{g}$ sediment $(0.0015$ to 0.0093 wt\% P; Fig. 4B), with peak values from 5 to $15 \mu \mathrm{mol} \mathrm{P/g} \mathrm{sediment} \mathrm{(} 0.015$ to $0.046 \mathrm{wt} \% \mathrm{P}$; Fig. 4B) from 8 to $11 \mathrm{Ma}$. A general decrease in iron-bound $\mathrm{P}$ occurs with age and depth, with concentrations of $2.0 \pm 0.2$ at the top of the record (from $0-0.5 \mathrm{Ma}$ ), and $1.2 \pm 0.1 \mu \mathrm{mol} \mathrm{P} / \mathrm{g}$ sediment below $10 \mathrm{Ma}$. The decrease for iron-bound $\mathrm{P}$ probably results from microbial iron and manganese reduction intermediate between aerobic respiration and sulfate reduction on redox scales. Sulfate interstitial-water profiles (Mayer, Pisias, Janecek, et al., 1992) show that sulfate concentrations in these sites generally decrease with age and depth; these decreases are of similar age and depth scales as the decreases observed in iron-bound P. Reduction of Fe and Mn oxyhydroxides, occurring just above the level of sulfate reduction, leads to the release of $\mathrm{P}$ from these compounds and results in decreasing iron-bound $\mathrm{P}$ concentrations with age and depth.

Strong variability beyond the minor diagenetically-produced depth changes occur at all sites. The peak in the iron-bound P profile between 8 and 11 Ma represents a 10-fold increase for Site 844 and a three-fold increase for Site 846 over values above and below the peak. Though it occurs at equivalent ages, the peak is from 50 to $80 \mathrm{~m}$ for Site 844 and 300 to $350 \mathrm{~m}$ for Site 846 . A peak occurs at $10.4 \mathrm{Ma}(300 \mathrm{~m})$ at the western Site 851 to about 10 times baseline values, though the peak is indicated by one data point only. Peaks also occur for Site 846 around $4 \mathrm{Ma}$ and for Sites 846 and 844 around $2 \mathrm{Ma}$. High iron-bound P concentrations must be the result of (1) low biogenic sedimentation rates, with little dilution of the detrital Fe flux and long P scavenging times for surficial sediment Fe-compounds, (2) high fluxes of Fe to the sediments and thus high $\mathrm{Fe}$-scavenged $\mathrm{P}$ values, (3) a diagenetic reaction which, unlike microbial Fe reduction, acts to mobilize and oxidize a large amount of $\mathrm{Fe}$ at a specific horizon (a period of high bottom water and surficial sediment oxygen level?), or (4) scavenging of $P$ after release from another P-bearing component after burial. Sedimen-

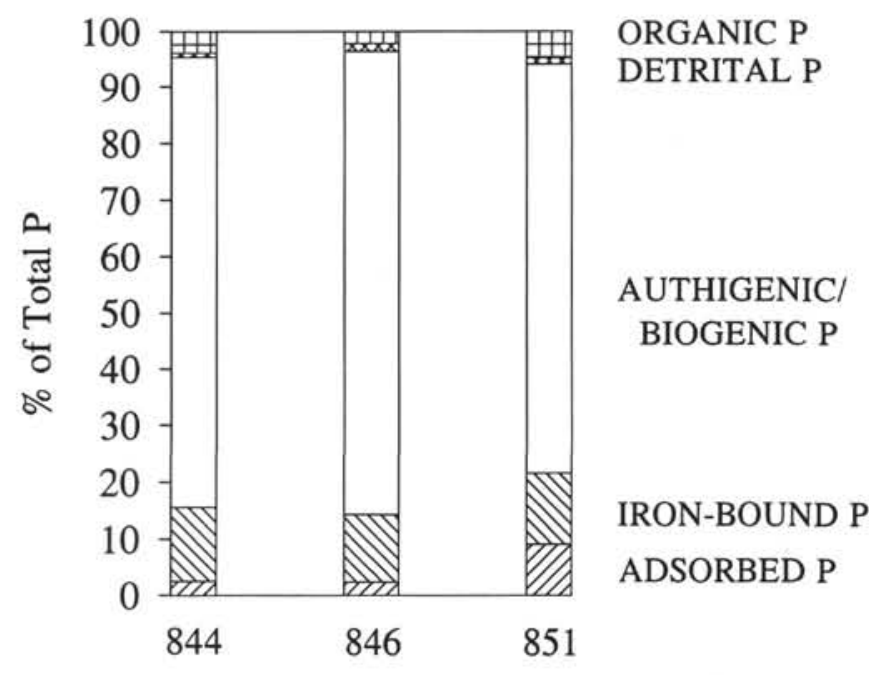

Figure 3. Percent of total $\mathrm{P}$ in each sedimentary component as the mean of all samples at each site (Site $844, n=34$, age range of samples is 17.0 to $6.8 \mathrm{Ma}$; Site $846, n=22$, age range of samples is 16.0 Ma to present; Site $851, n=68$, age range of samples is $12.4 \mathrm{Ma}$ to present).

tation rates (Tables A1-A3; Shackleton et al., this volume) are relatively high at all sites during this interval, and therefore a lack of dilution is not a reasonable possibility for the peak. The net result of the other three possibilities would be a horizon with high $\mathrm{Fe}$ concentrations, but there would be no way to distinguish between the processes. Magnetic susceptibility curves for these intervals do not give evidence for a horizon of high $\mathrm{Fe}$ concentrations, though core photos from Site 846 do show some darkening in the Fe-bound P-rich interval. Geochemical results (Leinen, this volume) indicate higher "hydrothermal" Fe fluxes (normalized to remove terrigenously derived $\mathrm{Fe}$ ) during the interval from 8 to $11 \mathrm{Ma}$ for Sites 844 and 851 (Site 846 results did not include this interval), though only to twice or three times previous values. Because of the large surface area (about $500 \mathrm{~m}^{2} / \mathrm{g}$ ) and high affinity for phosphate-binding of iron oxides and oxyhydroxides (Froelich, 1988), this increase in Fe flux is enough to yield 10 -fold increases in Fe-bound $\mathrm{P}$ concentrations. The source of the increase in Fe fluxes is unknown; it might be due to an increase or rearrangement of mid-ocean ridge spreading and volcanism. Note, however, that Leinen (this volume) observes other peaks in Fe fluxes of similar magnitude that do not correspond with any increases in Fe-bound $\mathrm{P}$ concentrations.

\section{Authigenic/Biogenic P}

Authigenic/biogenic $\mathrm{P}$ is associated with authigenic $\mathrm{P}$-rich minerals and biogenic debris. Sherwood et al. (1987) determined that latticebound $\mathrm{P}$ concentrations in foraminiferal calcium carbonate were low (less than $1 \mu \mathrm{mol} \mathrm{P} / \mathrm{g}$ ) and concluded that the observation of relatively high $\mathrm{P}$ concentrations in biogenic calcium carbonate debris (Froelich et al., 1982) was the result of overgrowths of iron oxyhydroxide. Although the extraction step that releases the authigenic/biogenic component also dissolves calcium carbonate, we found that the authigenic/ biogenic P component did not correlate with sedimentary calcium carbonate concentrations. Because iron oxyhydroxide overgrowths are removed in the prior extraction step, the authigenic/biogenic P component is probably associated with authigenic carbonate fluorapatite and with apatitic debris of biogenic origin, and not with calcium carbonate or iron oxyhydroxides.

Concentrations of authigenic/biogenic $\mathrm{P}$ range from 2 to $30 \mu \mathrm{mol}$ $\mathrm{P} / \mathrm{g}$ sediment (0.006 to $0.09 \mathrm{wt} \% \mathrm{P} ; \mathrm{Fig}$. 4C). The record from the western Site 851 displays relatively constant values from about 12 to $0 \mathrm{Ma}$, though $\mathrm{P}$ concentrations are more variable from 12 to $9 \mathrm{Ma}$ 

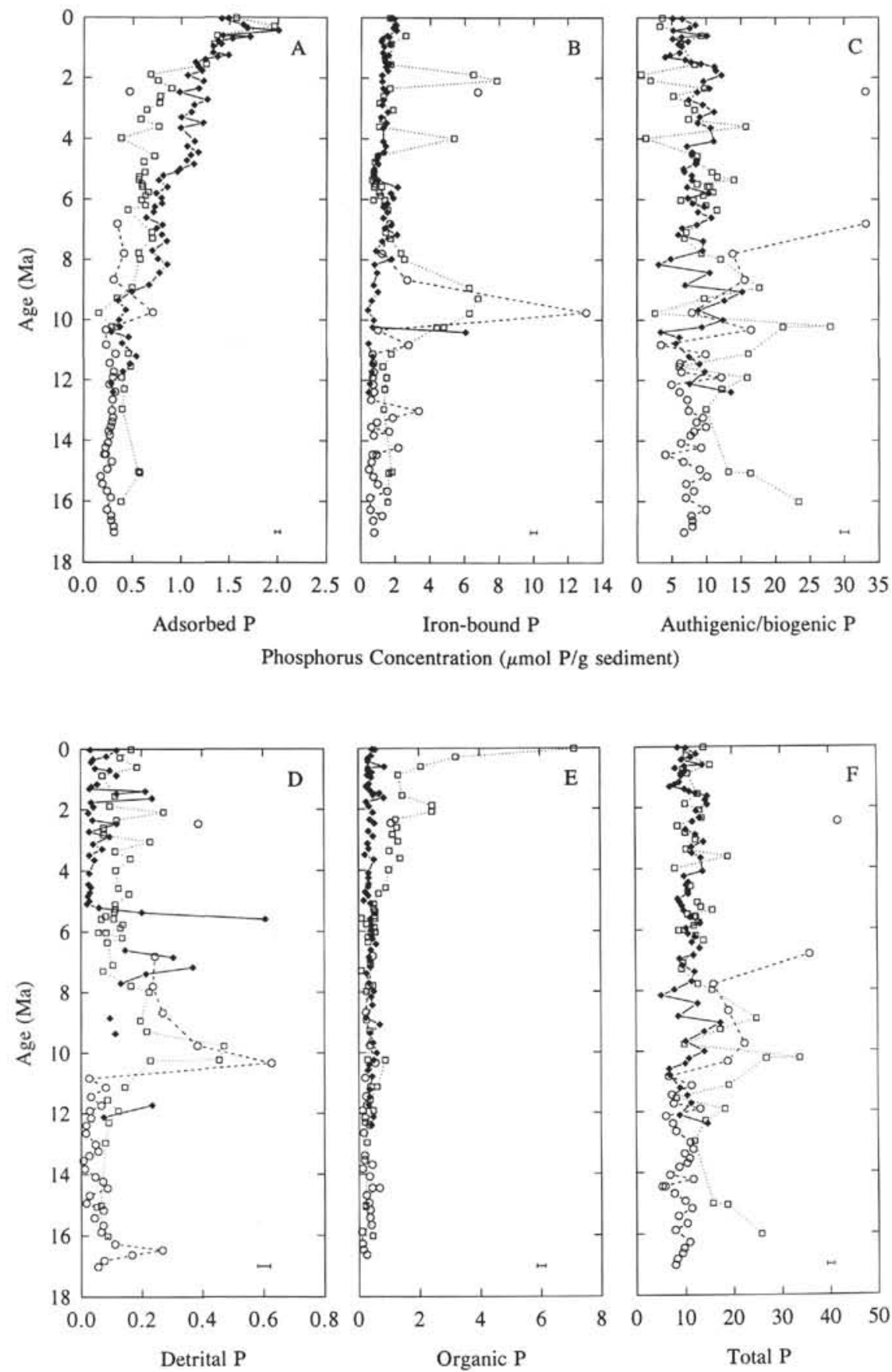

Phosphorus Concentration ( $\mu \mathrm{mol} \mathrm{P} / \mathrm{g}$ sediment)

Figure 4. Phosphorus concentrations ( $\mu \mathrm{mol} \mathrm{P} / \mathrm{g}$ sediment) of the five sedimentary $\mathrm{P}$ components and total $\mathrm{P}$ (the sum of the individual components) vs. age for northeastern Site 844 (open circles and dashed lines), southeastern Site 846 (open squares and dotted lines), and western Site 851 (filled diamonds and solid lines). A. Adsorbed P. B. Iron-bound P. C. Authigenic/biogenic P. D. Detrital P. E. Organic P. F. Total P. Note different horizontal scales for different P components. Error bars on the lower right of each plot represent typical $1 \sigma$ standard deviations on replicate sample determinations (see Table 3 ).

compared to the more recent record. Values for the northeastern Site 844 are also relatively constant, with similar values to Site 851 from $17 \mathrm{Ma}$ to about $11 \mathrm{Ma}$. Younger than $11 \mathrm{Ma}$, values for Site 844 are variable and increase to one of the highest values recorded for this component (at about $5 \mathrm{Ma}$ ). Values for the southeastern Site 846 decrease to about $15 \mathrm{Ma}$, after which the record is variable until $8 \mathrm{Ma}$. Younger than $8 \mathrm{Ma}, \mathrm{P}$ concentration values are relatively constant at similar values to those observed in the older portions of the western and south eastern sites. From these results, it appears that the overall "background" value for this component is about $8 \mu \mathrm{mol} \mathrm{P} / \mathrm{g}$ sediment, and that during certain intervals values can greatly exceed this concentration (though they rarely reach very low values). High and variable values in the interval from about 12 to $6 \mathrm{Ma}$ are seen in all sites.

\section{Detrital P}

Concentrations of detrital $\mathrm{P}$, associated with detrital fluorapatite, certain clays, and any residual phase not dissolved in weak acid, range 
from below detection limit (less than $0.01 \mu \mathrm{mol} \mathrm{P} / \mathrm{g}$ sediment) to 0.6 $\mu \mathrm{mol} \mathrm{P} / \mathrm{g}$ sediment (less than 0.00003 to $0.0018 \mathrm{wt} \% \mathrm{P}$; Fig. 4D). Because of a combination of very low $\mathrm{P}$ concentrations relative to the detection limit (due to the low supernatant $\mathrm{pH}$ inhibiting color development during $\mathrm{P}$ absorbance determinations), many samples are below this limit (Table 3). Furthermore, the mean error percentage on replicate determinations is relatively high for this component compared to the others. Given those cautions, however, some important features of this $\mathrm{P}$ concentration profile exist. There are indications of higher detrital $\mathrm{P}$ values for samples with higher iron-bound or authigenic/biogenic P values; because of the completeness of these two chemical extraction steps, this cannot be due solely to extraction artifacts. Also, though low for all three sites, detrital $\mathrm{P}$ is below detection limits for many samples from Site 851 . This is probably the result of a greater distance away from a terrigenous source area for this western transect site $(3500 \mathrm{~km})$, compared to that of the two eastern transect sites (about $600 \mathrm{~km}$ ).

\section{Organic $P$}

Concentrations of organic $\mathrm{P}$, associated with organic matter, range from 0.1 to $1.5 \mu \mathrm{mol} \mathrm{P} / \mathrm{g}$ sediment $(0.0003$ to $0.0046 \mathrm{wt} \%$ P; Fig. 4E), although values as high as $7 \mu \mathrm{mol} \mathrm{P} / \mathrm{g}$ sediment occur toward the top of the Site 846 record. Again, because of low concentrations and high relative detection limits, the mean error percentage is relatively high for this component. Therefore, the variability in this profile is probably analytical in origin. In general, there is a decrease in organic $\mathrm{P}$ from 0 to $18 \mathrm{Ma}$ for Site 846 , with the greatest rate of decrease occurring from 0 to $1 \mathrm{Ma}$ (Fig. 4E). Site 851 may also exhibit a decrease in organic P concentrations from 0 to $18 \mathrm{Ma}$, although such a decrease is not as clear as that for Site 846. This decrease in organic P may have resulted from the progressive oxidation of organic matter, although shipboard measurements of sedimentary organic carbon were almost always below detection limits in sediments prior to $1 \mathrm{Ma}$ (Mayer, Pisias, Janecek et al., 1992). Site 846 displays much higher near-surface organic P concentrations than Site 851, perhaps due to a higher rain rate of organic matter to Site 846 (influenced by Peru Current upwelling). It is interesting to note that, even though nearsurface organic $\mathrm{P}$ concentrations may differ between sites, values are quite similar after about 5 m.y. of burial.

\section{Total P}

Concentrations of total $\mathrm{P}$, the sum of all the components, range from about 8 to $40 \mu \mathrm{mol} \mathrm{P} / \mathrm{g}$ sediment ( 0.026 to $0.128 \mathrm{wt} \% \mathrm{P}$; Fig. $4 \mathrm{~F})$. The overall profile of this component primarily reflects that of the authigenic/biogenic component (the most important in terms of $\mathrm{P}$ concentrations), though the high iron-bound $\mathrm{P}$ values from 11 to $8 \mathrm{Ma}$ for eastern Sites 844 and 846 are also reflected.

\section{Phosphorus Accumulation Rates}

Phosphorus mass accumulation rates (P-MARs; $\mu \mathrm{mol} \mathrm{P} \cdot \mathrm{cm}^{-2}$. k. . $^{-1}$ ) should reflect the output fluxes of this biologically limiting nutrient from the oceans and, on steady-state time scales, variations in the input fluxes and in removal in other sinks (e.g., continental margin sediments). Total $\mathrm{P}$ accumulation rates reported in Tables A1 through $\mathrm{A} 3$ were calculated from the $\mathrm{P}$ concentrations of all the sedimentary components. Detrital P, typically less than $1 \%$ of total P, enters and exits the oceanic reservoir with no influence on or reflection of productivity and reactive $\mathrm{P}$ fluxes, and is of less interest for this discussion. Therefore, P-MARs presented in Figure 5 are calculated from the sum of adsorbed, iron-bound, authigenic/biogenic, and organic P components.

Overall, P-MARs for Leg 138 Sites 844,846 , and 851 decrease from $17 \mathrm{Ma}$ to the present (Fig. 5). From 17 to $8 \mathrm{Ma}$, P-MARs for the eastern transect Sites 844 and 846 decrease, though a great degree of variability is found in the record, and western transect Site 851

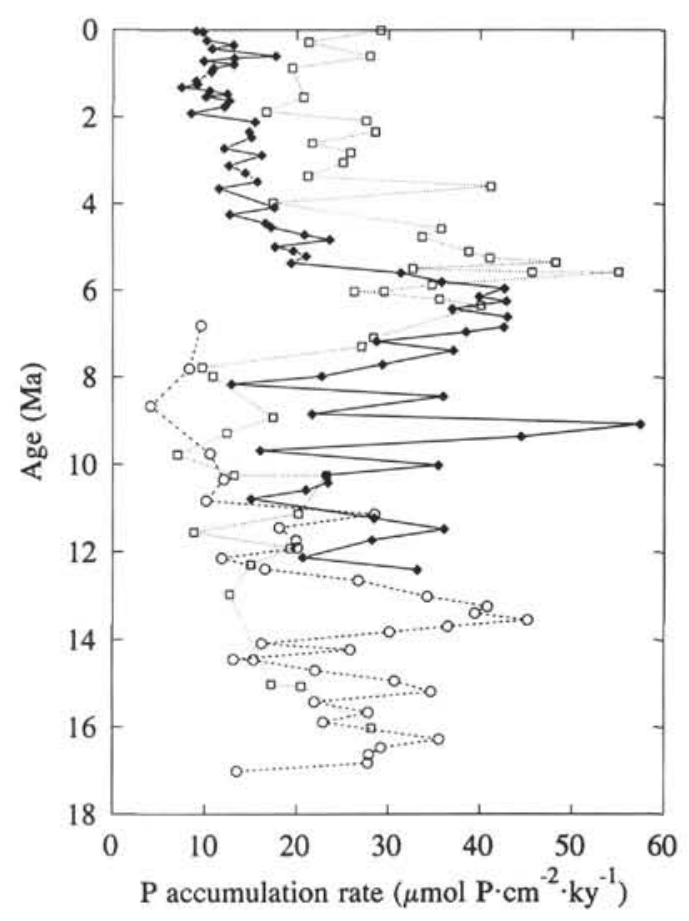

Figure 5. Phosphorus accumulation rates (P-MARs in $\mu \mathrm{mol} \mathrm{P} \cdot \mathrm{cm}^{-2} \cdot \mathrm{k} \cdot \mathrm{y} .^{-1}$ ) vs. age for northeastern Site 844 (open circles and dashed lines), southeastern Site 846 (open squares and dotted lines), and western Site 851 (filled diamonds and solid lines). Rates were calculated from the sum of adsorbed, iron-bound, authigenic/biogenic, and organic $\mathrm{P}$ component concentrations (not total $\mathrm{P}$ values reported in Tables A1-A3, which include the minor and oceanically unreactive detrital $\mathrm{P}$ component) and sedimentation rates and dry-bulk densities averaged over time intervals of 0.5 m.y. (discussed in the text).

P-MARs are variable from 13 to $8 \mathrm{Ma}$. P-MARs increase and stay relatively high from about 8 to $6 \mathrm{Ma}$ for Sites 846 and 851 , then decrease toward the present to some of the lowest values of the record for Sites 846 and 851 (Fig. 5). The eastern Sites 844 and 846 display comparable P-MAR values and trends where their records overlap. The western Site 851 has generally higher P-MARs than the eastern sites, displays greater variability in P-MARs in the older record, and is similar to Site 846 in the interval of increasing values from 8 to about $6 \mathrm{Ma}$. However, the different sample age intervals chosen for the sites result in different overlaps between the various P-MAR records. Also, sample spacing vs. age is different among the sites. Although samples were taken at the frequency of one sample for every five sections of core, different sedimentation rates for different sites and core intervals resulted in samples that were not taken at the same frequency vs. an age scale. Also, samples were taken at a higher frequency of one sample per one section of core for Site 851 from 7 Ma to the present.

The higher resolution sampling from the western Site 851 (one sample per section in the interval from $7 \mathrm{Ma}$ to the present) revealed interesting aspects of $\mathrm{P}$ removal on various time scales. Recalling that the residence time of $\mathrm{P}$ with respect to input or removal is about $100,000 \mathrm{yr}$, steady-state P fluxes will balance on time scales of 500,000 yr (about five times the residence time of an element) in response to instantaneous changes in these fluxes. If changes in P fluxes are of long duration or continuous, fluxes in the steady-state P balance will display continuing changes as well. The Site 851 record indicates P-MARs generally does not fluctuate dramatically on substeady-state time scales. However, clear variations in P-MARs can be seen on steady-state time scales. This is seen in the transition from high $\mathrm{P}$ MAR values during the interval of 7 to $6 \mathrm{Ma}$ to low values after 6 $\mathrm{Ma}$, indicating the stability of two different steady-state $\mathrm{P}$ balances. 
Furthermore, the decrease in P-MARs after 6 Ma shows a few deviations, but generally indicates a steady-state decrease in Poutput fluxes at this site.

We calculated P-MAR results (Tables A1-A3; Fig. 5) using sedimentation rates and dry-bulk densities (DBD, generally measured twice per section) averaged over 0.5-m.y. time steps (e.g., 0-0.5 Ma, 0.5-1.0 Ma, etc.). This calculation reflects an assumption that averages for the time steps best avoid artifacts from stratigraphic uncertainties and from differences in DBD between our samples and the sediments actually sampled. Figure 6 compares P-MARs calculated using three sets of assumptions for the 4 to 8-Ma interval in Site 851, a time interval having large variations in P-MARs. These curves result from using (1) 0.5 -m.y. averages of sedimentation rate and DBD (as in Fig. 5); (2) 0.5-m.y. averages of sedimentation rate and individual section average DBD; and (3) fine-scale sedimentation rates from an orbitally tuned time scale (often calculated for intervals as small as 20-100 k.y. or depth ranges of $0.2-1.2 \mathrm{~m}$; see Shackleton et al., this volume, for discussion) and individual section average DBD. Though general trends in P-MARs are preserved, the different methods of calculation result in distinctly different $P$-MAR values for many individual samples (Fig. 6). This type of comparison is important, as all accumulation rate results depend on sedimentation rate and dry-bulk density, parameters that are typically not examined in terms of the effect of time averaging on accumulation rates. The high-resolution sedimentation rates available for Leg 138 makes this comparison possible.

Using individual section average DBD yields a relatively small variation in P-MAR, compared to the values we presented (Fig. 6). Individual section DBD measurements are taken at discrete core locations which almost always differ from the exact location where our samples were taken. The range in DBD for two measurements on an individual section is often $\pm 25 \%$; we can assume that our sample has an actual DBD value that may differ from the individual section DBD average by that much as well. Because, apart from actually measuring DBD of our individual samples, we cannot calculate an accurate individual DBD value, we chose the 0.5 -m.y. average DBD as a reasonable approximation.

Using fine-scale sedimentation rates yields the largest variation in P-MARs (Fig. 6). These rates, though useful for understanding variations in sedimentation, may be strongly affected by uncertainties in composite stratigraphies and age picks from the orbitally-tuned record. These uncertainties may, in part, result in the large variations in P-MARs over small intervals observed for the fine-scale sedimentation rate calculation. We chose to use the 0.5 -m.y. averages for sedimentation rates.

The $0.5-\mathrm{m} . \mathrm{y}$. averages are geochemically appropriate, because steady-state variations in the oceanic $\mathrm{P}$ balance in terms of fluxes are on time scales of about 0.5 m.y. The implications of this calculation exercise are significant, as these types of uncertainties enter into most calculations of accumulation rates, frequently with little discussion of the assumptions involved.

The peak in P-MARs around $6 \mathrm{Ma}$ and decrease after $4 \mathrm{Ma}$ corresponds to a similar trend in sedimentation rates during this interval in the eastern equatorial Pacific (Mayer, Pisias, Janecek, et al., 1992; Shackleton et al., this volume). The peak also correlates with high sedimentation rates in the western equatorial Pacific (Berger, Kroenke, Mayer, et al., 1991) and the North Pacific (J. Barron, pers. comm., 1993), diatom productivity events in the Pacific and possibly Atlantic (Kemp and Baldauf, 1993; Kemp et al., this volume), and relatively positive $\delta^{13} \mathrm{C}$ values in carbonate sediments (Shackleton, 1987). All of these events indicate an interval of higher net burial and presumably higher $\mathrm{P}$ fluxes to surface waters at around $6 \mathrm{Ma}$. Furthermore, sedimentation rates, diatom productivity events, and $\delta^{13} \mathrm{C}$ values, as well as P-MAR values from our study and that of Moody et al. (1988), decrease (or become more negative) from about $6 \mathrm{Ma}$ to the present, indicating a trend toward lower net burial and $\mathrm{P}$ fluxes.

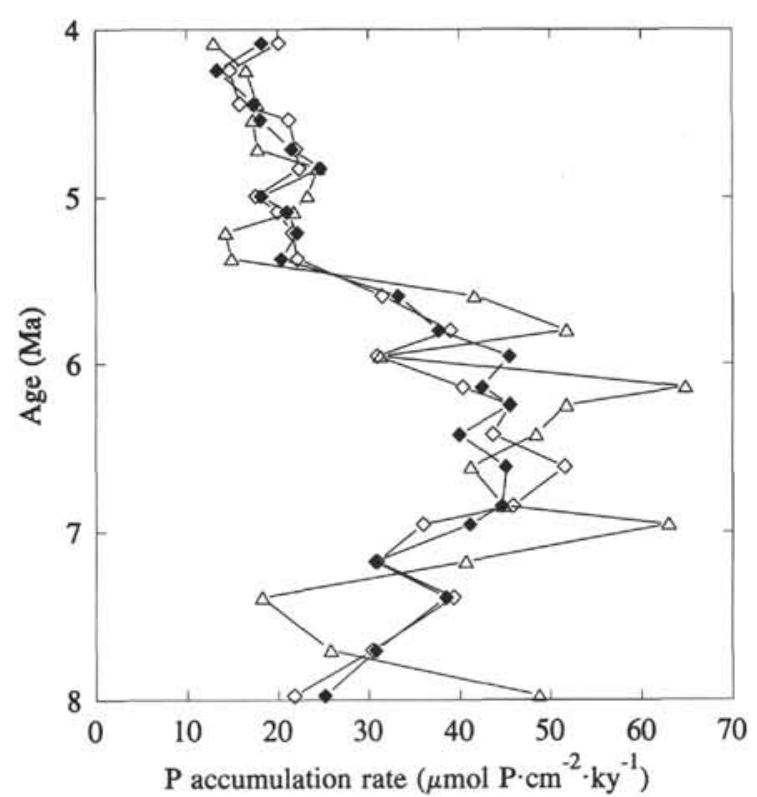

Figure 6. Phosphorus accumulation rates (P-MARs in $\mu \mathrm{mol} \mathrm{P} \cdot \mathrm{cm}^{-2} \cdot \mathrm{k} \cdot \mathrm{y} \cdot{ }^{-1}$ ) for western Site 851 from 8 to $4 \mathrm{Ma}$, calculated from using three different methods of defining applicable sedimentation rate and dry-bulk density values: filled diamond, 0.5-m.y. mean sedimentation rates and 0.5-m.y. mean dry-bulk densities used in Figure 5 and all tables here; open diamonds, 0.5-m.y. mean sedimentation rates and individual section dry-bulk densities; open triangles, using fine-scale sedimentation rates (commonly over age ranges of 20-100 k.y. or depth ranges of $0.2-1.2 \mathrm{~m}$ ) from an orbitally tuned age model (Shackleton et al., this volume) and individual section dry-bulk densities. Both fine-scale and 0.5-m.y. mean sedimentation rates are from Shackleton et al. (this volume), individual section dry-bulk densities are from Mayer, Pisias, Janecek, et al. (1992), and 0.5-m.y. mean dry-bulk densities were calculated as the mean of individual section dry-bulk densities.

Were these trends in $\mathrm{P}$ accumulation rates restricted to the Pacific Ocean, the two possibilities for their causes would be (1) a high flux of $\mathrm{P}$ to the oceans and high net $\mathrm{P}$ burial in sediments around $6 \mathrm{Ma}$ that decreases to the present, or (2) the redistribution of net $\mathrm{P}$ burial to regions not yet sampled. Though the first scenario seems more plausible given the large areal coverage of these data sets, the second scenario may be supported by an apparent "tightening" of productivity gradients in the eastern equatorial Pacific (Hagelberg et al., this volume) and the northeastern Pacific (J. Barron, pers. comm., 1993). A tightening of productivity and sedimentation gradients may lead to an apparent decrease in productivity indicators with time over a broad area, when net burial and productivity actually remained the same, but was just concentrated in smaller regions that may not have been adequately sampled as yet.

Evidence exists from diatom productivity events and $\delta^{13} \mathrm{C}$ profiles to show that the pattern of higher relative net $\mathrm{P}$ burial around $6 \mathrm{Ma}$, followed by lower $\mathrm{P}$ burial toward the present, is global in nature. If this is the case, a simple redistribution of nutrient fluxes and productivity with no change in net burial is not likely. Note, however, that productivity and deposition along continental margins is difficult to quantify because of sea-level oscillations and reworking of marginal sediments and may prove to be an important source of uncertainties in productivity and burial estimates.

\section{CONCLUSIONS}

Total P concentrations in Leg 138 samples ranged from 4 to 35 $\mu \mathrm{mol} \mathrm{P} / \mathrm{g}$ sediment, with mean values relatively similar between the three sites $(11,14$, and 12 for Sites 844,846 , and 851 , respectively). 
Authigenic/biogenic $\mathrm{P}$ was the most important component in terms of percentage of total $\mathrm{P}$ (about $75 \%$ ); with iron-bound $\mathrm{P}(13 \%)$, adsorbed $\mathrm{P}(2 \%-9 \%)$, and organic P (4\%) of secondary importance: detrital P was a minor P sink (1\%) in these sediments. Profiles of adsorbed P, organic $\mathrm{P}$, and iron-bound $\mathrm{P}$ show decreasing concentrations with age, indicating that these components are affected by diagenesis and reorganization of P. A peak in iron-bound P may indicate higher fluxes of hydrothermally derived $\mathrm{Fe}$ to eastern equatorial Pacific sediments from 11 to $8 \mathrm{Ma}$. Low detrital P values for the western Site 851 reflect the greater distance of this site from a terrigenous source area compared to Sites 844 and 846 .

Phosphorus accumulation rates decrease in the interval from about 17 to $8 \mathrm{Ma}$, increase and stay relatively high from 8 to $6 \mathrm{Ma}$, then decrease toward the present to some of the lowest values of the record. The general trend of high P-MARs at about $6 \mathrm{Ma}$ and decreasing values toward the present is correlated with other geochemical and sedimentary trends through this interval, indicating a global change in the P mass balance.

\section{ACKNOWLEDGMENTS}

This work was supported by a JOI/USSAC Ocean Drilling Program Graduate Fellowship and a National Defense Science and Engineering Graduate Fellowship to GMF, and the National Science Foundation (OCE89-11530 to MLD); these sources are graciously acknowledged. We thank Leg 138 Co-Chief Scientists N. Pisias and L. Mayer and Staff Scientist T. Janecek for their encouragement, support, and willingness to assist this shore-based research, the Shipboard Scientific Party for collection of samples, the ODP staff for the opportunity to collect and analyze these samples, and N. Pisias, L. Mayer, N. Shackleton, C. Ravelo, M. Leinen, M. Levitan, R. Garrison, C. Moore, L. Linn, and S. Catlin for helpful discussions and advice; S. Ware and E. Oatney provided efficient and responsible laboratory assistance. We also thank R. Franks and the UCSC IMS Marine Analytical Laboratory for their consistent and high-quality support of this research. J. Compton and K. Ruttenberg provided helpful reviews that improved this manuscript.

\section{REFERENCES*}

Baturin, G.N., 1988. Disseminated phosphorus in oceanic sediments-a review. Mar. Geol., 84:95-104.

Berger, W.H., Kroenke, L.W., Mayer, L.A., and Shipboard Scientific Party, 1991. Ontong Java Plateau, Leg 130: synopsis of major drilling results. In Kroenke, L.W., Berger, W.H., Janecek, T.R., et al., Proc. ODP, Init. Repts., 130: College Station, TX (Ocean Drilling Program), 497-537.

Cande, S.C., and Kent, D.V., 1992. A new geomagnetic polarity time scale for the Late Cretaceous and Cenozoic. J. Geophys. Res., 97:13917-13951.

Cook, P.J., 1984. Spatial and temporal controls on the formation of phosphate deposits: a review. In Nriagu, J.O., and Moore, P.B. (Eds.), Phosphate Minerals: New York (Springer), 242-274.

Froelich, P.N., 1984. Interactions of the marine phosphorus and carbon cycles. In Moore, B., and Dastoor, M.N. (Eds.), The Interaction of Global Biogeochemical Cycles. NASA-JPL Publ. 84-21:141-176.
1988. Kinetic control of dissolved phosphate in natural rivers and estuaries: a primer on the phosphate buffer mechanism. Limnol. Oceanogr., 33:649-668,

Froelich, P.N., Bender, M.L., and Heath, G.R., 1977. Phosphorus accumulation rates in metalliferous sediments on the East Pacific Rise. Earth Planet. Sci. Lett., 34:351-359.

Froelich, P.N., Bender, M.L., Luedtke, N.A., Heath, G.R., and DeVries, T., 1982. The marine phosphorus cycle. Am. J. Sci., 282:474-511.

Kemp, A.E.S., and Baldauf, J.G., 1993. Vast Neogene laminated diatom mat deposits from the eastern equatorial Pacific Ocean. Nature, 362:141-144.

Mach, D.M., Ramirez, A., and Holland, H.D., 1987. Organic phosphorus and carbon in marine sediments. Am. J. Sci., 278:429-441.

Mayer, L., Pisias, N., Janecek, T., et al., 1992. Proc. ODP, Init. Repts., 138 (Pts. 1 and 2): College Station, TX (Ocean Drilling Program).

Meybeck, M., 1982. Carbon, nitrogen, and phosphorus transport by world rivers. Am. J. Sci., 282:401-450.

Moody, J.B., Chaboudy, L.R., and Worsley, T.R., 1988. Pacific pelagic phosphorus accumulation during the last 10 M.Y. Paleoceanography, 3:113136.

Moody, J.B., Worsley, T.R., and Manoogian, P.R., 1981. Long-term phosphorus flux to deep-sea sediments. J. Sediment. Petrol., 51:307-312.

Nirel, P.M.V., and Morel, F.M.M., 1991. Pitfalls of sequential extractions. Water Res., 24:1055-1056.

Ruttenberg, K.C., 1990. Diagenesis and burial of phosphorus in marine sediments: implications for the marine phosphorus budget [Ph.D. dissert.]. Yale Univ., New Haven, Conn.

1992. Development of a sequential extraction method for different forms of phosphorus in marine sediments. Limnol. Oceanogr., 37:14601482.

Ruttenberg, K.C., and Berner, R.A., 1993. Authigenic apatite formation and burial in sediments from non-upwelling, continental margin environments. Geochim. Cosmochim. Acta, 57:991-1007.

Shackleton, N.J., 1987. The carbon isotope record of the Cenozoic: history of organic carbon burial and of oxygen in the ocean and atmosphere. In Brooks, J., and Fleet, A.J. (Eds.), Marine Petroleum Source Rocks. Geol. Soc. Spec. Publ. London, 26:423-434.

Sherwood, B.A., Sager, S.L., and Holland, H.D., 1987. Phosphorus in foraminiferal sediments from North Atlantic Ridge cores and in pure limestones. Geochim. Cosmochim. Acta, 51:1861-1866.

Strickland, J.D.H., and Parsons, T.R., 1972. A Practical Handbook of Seawater Analysis: Ottawa (Fisheries Research Board of Canada).

Watanabe, F.S., and Olsen, S.R., 1962. Colorimetric determination of phosphorus in water extracts of soils. Soil Sci., 93:183-188.

Zhou, L., and Kyte, F.T., 1992. Sedimentation history of the south Pacific pelagic clay province over the last 85 million years inferred from the geochemistry of Deep Sea Drilling Project Hole 596. Paleoceanography, $7: 441-465$.

\footnotetext{
Abbreviations for names of organizations and publication titles in ODP reference lists follow the style given in Chemical Abstracts Service Source Index (published by American Chemical Society).
}

Date of initial receipt: 4 February 1993

Date of acceptance: 29 July 1993

Ms 138SR-144 
APPENDIX

Sample identifications, depths, ages, sedimentation rates, dry-bulk densities, component $P$ concentra-

tions (in units of $\mu \mathrm{mol} \mathrm{P} / \mathrm{g}$ sediment) and standard deviations, total $\mathrm{P}$ concentrations and standard

deviations, and total $P$ accumulation rates and standard deviations.

Table A1. Site 844.

\begin{tabular}{|c|c|c|c|c|c|c|c|c|c|c|c|c|c|c|c|c|c|c|}
\hline \multirow{2}{*}{$\begin{array}{l}\text { Core, section, } \\
\text { interval }(\mathrm{cm})\end{array}$} & \multirow{2}{*}{$\begin{array}{l}\text { Depth }{ }^{a} \\
\text { (mcd) }\end{array}$} & \multirow{2}{*}{$\begin{array}{l}\mathrm{Age}^{\mathrm{b}} \\
\text { (Ma) }\end{array}$} & \multirow{2}{*}{$\begin{array}{l}\text { Sed.rt.c } \\
(\mathrm{cm} / \mathrm{m} . \mathrm{y} .)\end{array}$} & \multirow{2}{*}{$\begin{array}{l}\mathrm{DBD}^{4} \\
\left(\mathrm{~g} / \mathrm{cm}^{3}\right)\end{array}$} & \multicolumn{2}{|c|}{ Adsorbed } & \multicolumn{2}{|c|}{ Iron-bound } & \multicolumn{2}{|c|}{ Auth.bio. } & \multicolumn{2}{|c|}{ Detrital } & \multicolumn{2}{|c|}{ Organic } & \multicolumn{2}{|c|}{ Total $^{\text {reg }}$} & \multicolumn{2}{|c|}{ Totalh } \\
\hline & & & & & {$[\mathrm{P}]$} & s.d. ${ }^{e}$ & {$[\mathrm{P}]$} & s.d. & {$[\mathrm{P}]$} & s.d. & {$[\mathrm{P}]$} & s.d. & {$[\mathrm{P}]$} & s.d. & {$[\mathrm{P}]$} & s.d. & Pacc. & s.d. \\
\hline \multicolumn{19}{|l|}{ 138-844B- } \\
\hline $5 \mathrm{H}-3,60-62$ & 40.3 & 6.810 & 5.74 & 0.44 & 0.366 & 0.007 & 1.86 & 0.02 & 33.34 & 0.02 & 0.209 & 0.007 & 0.74 & 0.46 & 36.5 & 0.5 & 9.2 & 0.1 \\
\hline $6 \mathrm{H}-1,59-61$ & 47.3 & 7.806 & 11.08 & 0.43 & 0.440 & 0.063 & 1.35 & 0.06 & 13.91 & 7.97 & 0.204 & 0.008 & 0.52 & 0.45 & 16.4 & 8.0 & 7.8 & 3.8 \\
\hline $6 \mathrm{H}-6,60-62$ & 54.7 & 8.668 & 7.30 & 0.32 & 0.327 & 0.060 & 2.97 & 0.60 & 15.65 & 0.16 & 0.232 & 0.026 & 0.38 & 0.12 & 19.6 & 0.6 & 4.6 & 0.1 \\
\hline $7 \mathrm{H}-4,60-62$ & 63.8 & 9.753 & 11.72 & 0.30 & 0.758 & 0.025 & 14.40 & 1.17 & 7.97 & 0.40 & 0.331 & 0.011 & 0.58 & 0.04 & 24.0 & 1.2 & 8.3 & 0.4 \\
\hline $8 \mathrm{H}-2,60-62$ & 70.7 & 10.337 & 11.22 & 0.34 & 0.246 & 0.006 & 2.53 & - & 16.55 & 0.20 & 0.533 & 0.016 & 1.77 & - & 21.6 & 0.2 & 8.2 & 0.1 \\
\hline $8 \mathrm{H}-7,56-58$ & 78.2 & 10.828 & 19.10 & 0.56 & 0.250 & 0.008 & 3.05 & 1.59 & 3.46 & 1.42 & 0.023 & 0.005 & 0.32 & 0.23 & 7.1 & 2.1 & 7.5 & 2.3 \\
\hline $9 \mathrm{H}-5,60-62$ & 86.3 & 11.136 & 32.80 & 0.78 & 0.350 & 0.024 & 0.76 & 0.34 & 9.97 & 0.27 & 0.070 & 0.026 & 0.63 & 0.51 & 11.8 & 0.7 & 30.3 & 1.7 \\
\hline $10 \mathrm{H}-4,60-62$ & 96.2 & 11.442 & 32.80 & 0.78 & 0.282 & 0.063 & 0.78 & 0.13 & 6.13 & 0.37 & 0.028 & 0.012 & 0.37 & 0.00 & 7.6 & 0.4 & 19.5 & 1.0 \\
\hline $11 \mathrm{H}-3,60-62$ & 107.1 & 11.731 & 37.36 & 0.77 & 0.327 & 0.008 & 0.82 & 0.10 & 6.34 & 0.25 & 0.057 & 0.037 & 0.42 & 0.47 & 8.0 & 0.5 & 22.9 & 1.5 \\
\hline $12 \mathrm{H}-1,60-62$ & 113.6 & 11.904 & 37.36 & 0.77 & 0.317 & 0.012 & 0.74 & 0.27 & 6.48 & & 0.024 & 0.005 & 0.18 & 0.13 & 7.7 & 0.3 & 22.2 & 0.9 \\
\hline $12 \mathrm{H}-6,60-62$ & 121.1 & 12.146 & 27.64 & 0.71 & 0.279 & 0.03 & 0.78 & 0.26 & 4.93 & 0.17 & 0.027 & 0.00 & 0.33 & 0.30 & 6.4 & 0.4 & 12.5 & 0.9 \\
\hline $13 \mathrm{H}-4,59-61$ & 127.9 & 12.391 & 27.64 & 0.71 & 0.340 & 0.024 & 0.85 & 0.24 & 6.10 & 0.31 & 0.015 & 0.008 & 0.57 & 0.68 & 7.9 & 0.8 & 15.5 & 1.5 \\
\hline $14 \mathrm{H}-2,60-62$ & 135.4 & 12.653 & 39.70 & 0.82 & 0.314 & 0.063 & 0.65 & 0.08 & 7.23 & 0.41 & 0.013 & 0.005 & 0.25 & 0.21 & 8.5 & 0.5 & 27.6 & 1.5 \\
\hline $15 \mathrm{H}-6,60-62$ & 151.1 & 13.010 & 44.92 & 0.88 & 0.308 & 0.026 & 0.94 & - & 7.45 & 0.04 & 0.040 & 0.001 & 0.87 & - & 9.6 & 0.0 & 37.8 & 0.2 \\
\hline $16 \mathrm{H}-5,60-62$ & 160.3 & 13.247 & 44.92 & 0.88 & 0.319 & 0.051 & 0.52 & - & 9.52 & 0.03 & 0.048 & 0.004 & & - & 10.4 & 0.1 & 41.0 & 0.2 \\
\hline $17 \mathrm{H}-4,60-62$ & 167.7 & 13.392 & 44.95 & 0.88 & 0.310 & 0.062 & 1.03 & 0.15 & 8.56 & 0.13 & 0.022 & 0.001 & 0.29 & 0.18 & 10.2 & 0.3 & 40.3 & 1.1 \\
\hline $18 \mathrm{H}-2,60-62$ & 175.6 & 13.546 & 46.62 & 0.89 & 0.295 & 0.008 & 0.66 & 0.01 & 9.97 & 0.18 & 0.006 & 0.004 & 0.30 & 0.29 & 11.2 & 0.3 & 46.4 & 1.4 \\
\hline $18 \mathrm{H}-7,60-62$ & $\begin{array}{l}183.2 \\
183.2\end{array}$ & $\begin{array}{l}13.690 \\
13.693\end{array}$ & $\begin{array}{l}40.02 \\
46.62\end{array}$ & 0.89 & 0.275 & 0.01 & 0.44 & -0.01 & 8.22 & 0.27 & - & 0.004 & 0.00 & $\frac{0.29}{-}$ & 8.9 & 0.3 & $\begin{array}{l}40.4 \\
36.9\end{array}$ & 1.1 \\
\hline $19 \mathrm{H}-5,60-62$ & $\begin{array}{l}189.7 \\
\end{array}$ & 13.820 & 46.62 & 0.89 & 0.286 & 0.08 & 0.81 & $0 . \overline{24}$ & 7.74 & 3.06 & 0.010 & $0 . \overline{009}$ & 0.19 & 0.13 & $\begin{array}{l}9.9 \\
9.0\end{array}$ & 3.1 & 37.4 & 12.7 \\
\hline $20 \mathrm{H}-4,60-62$ & 199.2 & 14.080 & 33.60 & 0.73 & 0.264 & 0.053 & - & - & 6.33 & 0.03 & 0.040 & 0.003 & 0.68 & 0.08 & 7.3 & 0.1 & 18.0 & 0.2 \\
\hline $21 \mathrm{H}-1,60-62$ & 204.2 & 14.229 & 33.60 & 0.73 & 0.241 & 0.029 & 0.98 & - & 9.29 & 0.15 & 0.060 & 0.007 & 0.54 & 0.07 & 11.1 & 0.2 & 27.4 & 0.4 \\
\hline $2 \mathrm{IH}-6,60-62$ & 211.7 & 14.451 & 33.60 & 0.73 & 0.228 & 0.000 & 0.30 & - & 4.03 & - & - & - & - & - & 4.6 & 0.0 & 11.2 & 0.0 \\
\hline $21 \mathrm{H}-6,60-62$ & 211.7 & 14.451 & 33.60 & 0.73 & 0.241 & 0.016 & 1.00 & 0.70 & 4.08 & 0.06 & 0.073 & 0.052 & 1.07 & 0.00 & 6.5 & 0.7 & 15.9 & 1.7 \\
\hline $22 X-5,60-62$ & 219.8 & 14.693 & 33.62 & 0.86 & 0.310 & 0.007 & 0.68 & 0.17 & 6.67 & 0.06 & 0.024 & 0.012 & 0.38 & 0.19 & 8.1 & 0.3 & 23.3 & 0.8 \\
\hline $23 X-4,60-62$ & 228.0 & $\begin{array}{l}14.093 \\
14.937\end{array}$ & $\begin{array}{l}33.02 \\
33.62\end{array}$ & 0.86 & 0.257 & 0.041 & 0.51 & 0.20 & 9.04 & 0.00 & 0.014 & 0.012 & 0.51 & 0.27 & $\begin{array}{l}0.1 \\
10.3\end{array}$ & 0.3 & 29.8 & $\begin{array}{l}.0 \\
1.0\end{array}$ \\
\hline $24 X-3,60-62$ & 236.1 & $\begin{array}{l}14.937 \\
15.178\end{array}$ & $\begin{array}{l}33.02 \\
33.62\end{array}$ & $\begin{array}{l}0.80 \\
0.93\end{array}$ & 0.185 & 0.04 & 0.80 & 0.13 & 10.10 & 2.28 & 0.063 & 0.031 & $\begin{array}{l}0.58 \\
0.58\end{array}$ & 0.47 & 11.7 & 2.3 & $\begin{array}{l}29.8 \\
36.7\end{array}$ & 7.3 \\
\hline $25 \mathrm{X}-2,60-62$ & 244.3 & 15.422 & 33.62 & 0.9 & 0.205 & 0.0 & 0.3 . & - & 7.07 & 0.1 & 0.037 & 0.0 & 0.69 & - & 8.4 & 0.1 & 26.1 & 0.4 \\
\hline $26 \mathrm{X}-1.58-60$ & 252.4 & 15.663 & 36.08 & 0.83 & 0.256 & 0.04 & 0.57 & $\overline{-}$ & 8.19 & 0.0 & 0.061 & 0.0 & 0.57 & $=$ & $\begin{array}{l}9.4 \\
9.6\end{array}$ & 0.1 & 28.9 & 0.2 \\
\hline $26 \mathrm{X}-6,59-61$ & 260.0 & 15.878 & 36.08 & 0.8 & 0.299 & 0.0 & 0.58 & 0.16 & 7.02 & 0.1 & 0.056 & 0.00 & 0.14 & 0.08 & 8.1 & 0.2 & 24.3 & 0.6 \\
\hline $28 X-4,55-57$ & 276.3 & 16.276 & 40.84 & 0.80 & 0.255 & 0.00 & 0.60 & 0.05 & 9.97 & 2.3 & 0.095 & 0.027 & 0.17 & 0.02 & 11.1 & 2.4 & 36.4 & 7.9 \\
\hline $29 \mathrm{X}-3,59-61$ & 284.1 & 16.468 & 40.84 & 0.80 & 0.300 & 0.052 & 1.38 & 0.65 & 7.84 & 2.37 & 0.230 & 0.033 & 0.22 & 0.05 & 10.0 & 2.5 & 32.7 & 8.2 \\
\hline $30 \times-1,59-61$ & 290.7 & $\begin{array}{l}10.400 \\
16.630\end{array}$ & 40.86 & 0.75 & 0.302 & 0.036 & 0.80 & 0.07 & 7.98 & 0.01 & 0.143 & 0.043 & 0.40 & 0.03 & 9.6 & 0.1 & 29.6 & 0.3 \\
\hline $30 \times-6,60-62$ & $\begin{array}{l}298.3 \\
298.1\end{array}$ & $\begin{array}{l}10.030 \\
16.816\end{array}$ & $\begin{array}{l}40.80 \\
40.86\end{array}$ & 0.75 & 0.328 & 0.07 & 0.80 & - & $\begin{array}{l}7.98 \\
7.99\end{array}$ & 0.58 & $\begin{array}{l}0.143 \\
0.064\end{array}$ & $\begin{array}{l}0.017 \\
0.017\end{array}$ & 0.65 & 0.15 & $\begin{array}{l}9.0 \\
9.0\end{array}$ & 0.6 & $\begin{array}{l}29.0 \\
27.8\end{array}$ & 1.9 \\
\hline $31 X-5,60-62$ & 306.4 & 17.014 & 20.80 & 0.89 & 0.336 & 0.034 & 0.46 & - & 6.77 & 0.07 & 0.047 & 0.003 & - & - & 7.6 & 0.1 & 14.1 & 0.1 \\
\hline
\end{tabular}

$-=$ Value not determined or not determinable: when indicated for standard deviations, only one replicate yielded a measurable result and, thus, no standard deviation can be calculated. bdl $=$ Value below

Composite depth in meters (mcd)

Ages from Shackleton et al. (this volume).

Mean sedimentation rate calculated over 0.5 -m.y. intervals (Shackleton et al., this volume)

Mean dry-bulk density over 0.5-m.y. intervals (calculated from Mayer, Pisias, Janecek et al., 1992).

${ }^{\mathrm{e}}$ Sample standard deviation $(1 \sigma)$.

Sum of the five sedimentary components.

Standard deviation calculated as the square root of the sum of the squared standard deviation values for the components.

Phosphorus accumulation rate (P-MAR in units of $\mu$ mol P $\cdot \mathrm{cm}^{-2} \cdot \mathbf{k} \cdot \mathrm{y}^{-1}$ ) calculated as the product of the total P concentration, the sedimentation rate, and the dry-bulk density, and divided by 10 to convert

P accumulation rate was not calculated for this basal metalliferous sediment sample because the sedimentation rate was not well-defined. 
Table A2. Site 846.

\begin{tabular}{|c|c|c|c|c|c|c|c|c|c|c|c|c|c|c|c|c|c|c|}
\hline \multirow{2}{*}{$\begin{array}{l}\text { Core, section, } \\
\text { interval (cm) }\end{array}$} & \multirow{2}{*}{$\begin{array}{l}\text { Deptha } \\
\text { (mcd) }\end{array}$} & \multirow{2}{*}{$\begin{array}{l}\mathrm{Age}^{\mathrm{b}} \\
\text { (Ma) }\end{array}$} & \multirow{2}{*}{$\begin{array}{l}\text { Sed.rt. }{ }^{\mathrm{c}} \\
(\mathrm{m} / \mathrm{m} \cdot \mathrm{y} .)\end{array}$} & \multirow{2}{*}{$\begin{array}{l}\mathrm{DBD}^{\mathrm{d}} \\
\left(\mathrm{g} / \mathrm{cm}^{3}\right)\end{array}$} & \multicolumn{2}{|c|}{ Adsorbed } & \multicolumn{2}{|c|}{ Iron-bound } & \multicolumn{2}{|c|}{ Auth./bio. } & \multicolumn{2}{|c|}{ Detrital } & \multicolumn{2}{|c|}{ Organic } & \multicolumn{2}{|c|}{ Total $^{\text {L }}$. } & \multicolumn{2}{|c|}{ Total $^{h}$} \\
\hline & & & & & {$[\mathrm{P}]$} & s.d. ${ }^{e}$ & {$[\mathrm{P}]$} & s.d. & {$[\mathrm{P}]$} & s.d. & {$[\mathrm{P}]$} & s.d. & {$[\mathrm{P}]$} & s.d. & {$[\mathrm{P}]$} & s.d. & Pacc. & s.d. \\
\hline \multicolumn{19}{|l|}{ 138-846B- } \\
\hline $1 \mathrm{H}-1,0-150$ & 0.8 & 0.014 & 39.62 & 0.501 & 1.571 & 0.000 & 1.68 & 0.25 & 3.62 & 0.08 & 0.166 & 0.003 & 7.15 & 0.24 & 14.2 & 0.4 & 27.8 & 0.7 \\
\hline $2 \mathrm{H}-3,0-150$ & 11.4 & 0.283 & 39.62 & 0.501 & 1.960 & 0.010 & 1.98 & 0.02 & 3.27 & 0.14 & 0.129 & 0.016 & 3.22 & 0.07 & 10.6 & 0.2 & 20.7 & 0.3 \\
\hline $3 \mathrm{H}-3,0-150$ & 22.3 & 0.601 & 33.56 & 0.538 & 1.371 & 0.003 & 2.59 & 0.01 & 9.29 & 0.12 & 0.185 & 0.021 & 2.07 & 0.11 & 15.5 & 0.2 & 27.7 & 0.3 \\
\hline $4 \mathrm{H}-3,0-150$ & 32.9 & 0.877 & 33.56 & 0.538 & 1.339 & 0.007 & 1.74 & 0.00 & 6.28 & 0.03 & 0.070 & 0.004 & 1.32 & 0.01 & 10.8 & 0.0 & 19.3 & 0.1 \\
\hline $6 \mathrm{H}-3,0-150$ & 55.3 & 1.548 & 40.34 & 0.399 & 1.257 & 0.020 & 1.73 & 0.04 & 8.32 & 0.02 & 0.112 & 0.000 & 1.46 & 0.00 & 12.9 & 0.0 & 20.5 & 0.1 \\
\hline $7 \mathrm{H}-4,0-150$ & 68.1 & 1.882 & 40.34 & 0.399 & 0.683 & 0.004 & 6.50 & 0.11 & 0.58 & 0.09 & 0.095 & 0.001 & 2.44 & 0.16 & 10.3 & 0.2 & 16.4 & 0.3 \\
\hline $8 \mathrm{H}-4,0-150$ & 79.0 & 2.085 & 43.52 & 0.482 & 0.759 & 0.005 & 7.86 & 0.47 & 1.94 & 0.19 & 0.273 & 0.016 & 2.43 & 0.14 & 13.3 & 0.5 & 27.2 & 1.1 \\
\hline $9 \mathrm{H}-4,0-150$ & 88.9 & 2.339 & 43.52 & 0.482 & 0.900 & 0.005 & 1.68 & 0.12 & 9.74 & 0.33 & 0.117 & 0.001 & 1.23 & 0.01 & 13.7 & 0.4 & 28.4 & 0.7 \\
\hline $10 \mathrm{H}-4,0-150$ & 100.8 & 2.602 & 47.96 & 0.521 & 0.782 & 0.010 & 1.30 & 0.32 & 5.22 & 0.31 & 0.075 & 0.000 & 1.28 & 0.01 & 8.7 & 0.4 & 21.4 & 1.1 \\
\hline $11 \mathrm{H}-4,0-150$ & 111.3 & 2.826 & 47.96 & 0.521 & 0.776 & 0.008 & 1.07 & 0.10 & 7.29 & 0.10 & 0.075 & 0.006 & 1.13 & 0.18 & 10.3 & 0.2 & 25.7 & 0.6 \\
\hline $12 \mathrm{H}-4,0-150$ & 122.1 & 3.051 & 38.76 & 0.529 & 0.643 & 0.026 & 1.86 & 0.45 & 8.32 & 0.80 & 0.228 & 0.028 & 1.31 & 0.01 & 12.4 & 0.9 & 24.9 & 1.8 \\
\hline $13 \mathrm{H}-4,0-150$ & 133.2 & 3.365 & 38.76 & 0.529 & 0.583 & 0.004 & 1.24 & 0.38 & 7.44 & 0.34 & 0.112 & 0.003 & 1.02 & 0.10 & 10.4 & 0.5 & 21.1 & 1.1 \\
\hline $14 \mathrm{H}-4,0-150$ & 143.4 & 3.602 & 33.98 & 0.637 & 0.768 & 0.010 & 1.06 & 0.05 & 15.73 & 0.17 & 0.163 & 0.019 & 1.38 & - & 19.1 & 0.2 & 41.0 & 0.3 \\
\hline $15 \mathrm{H}-4,0-150$ & 155.5 & 3.984 & 33.98 & 0.637 & 0.382 & 0.003 & 5.39 & 0.26 & 1.23 & 0.21 & 0.114 & 0.004 & 1.00 & - & 8.1 & 0.3 & 17.3 & 0.7 \\
\hline $17 \mathrm{H}-4,0-150$ & 176.0 & 4.574 & 45.12 & 0.697 & 0.724 & 0.010 & 0.97 & 0.03 & 8.72 & 0.49 & 0.123 & 0.002 & 0.90 & 0.00 & 11.4 & 0.5 & 35.6 & 1.5 \\
\hline $18 \mathrm{H}-4,0-150$ & 186.1 & 4.762 & 45.12 & 0.697 & 0.614 & 0.020 & 0.81 & 0.10 & 8.59 & 0.08 & 0.158 & 0.001 & 0.66 & 0.00 & 10.8 & 0.1 & 33.5 & 0.4 \\
\hline $19 \mathrm{H}-4,0-150$ & 197.6 & 5.105 & 40.96 & 0.746 & 0.624 & 0.007 & 0.72 & 0.02 & 10.84 & 0.02 & 0.112 & 0.002 & 0.50 & 0.01 & 12.8 & 0.0 & 38.7 & 0.1 \\
\hline $20 \mathrm{H}-1,0-150$ & 204.4 & 5.258 & 40.96 & 0.746 & 0.565 & 0.013 & 0.76 & 0.12 & 11.60 & 0.26 & 0.113 & 0.026 & 0.49 & 0.02 & 13.5 & 0.3 & 41.0 & 0.8 \\
\hline $20 \mathrm{H}-4,0-150$ & 208.9 & 5.356 & 40.96 & 0.746 & 0.562 & 0.005 & 0.65 & 0.12 & 14.01 & 0.34 & 0.109 & 0.005 & 0.54 & 0.01 & 15.9 & 0.4 & 48.2 & 1.1 \\
\hline & 215.2 & 5.494 & 40.96 & 0.746 & 0.594 & 0.018 & 0.84 & 0.00 & 8.68 & 0.28 & 0.081 & 0.001 & 0.53 & 0.02 & 10.7 & 0.3 & 32.6 & 0.8 \\
\hline $21 \mathrm{H}-4,0-150$ & 219.7 & 5.580 & 61.16 & 0.725 & 0.597 & 0.013 & 0.76 & 0.02 & 10.50 & 0.97 & 0.067 & 0.005 & 0.53 & 0.01 & 12.5 & 1.0 & 54.9 & 4.3 \\
\hline $21 \mathrm{H}-4,60-62$ & 220.0 & 5.576 & 61.16 & 0.729 & 0.601 & 0.424 & 1.20 & - & 10.19 & - & 0.107 & - & 0.10 & - & 12.2 & 0.4 & 53.9 & 1.9 \\
\hline $22 \mathrm{H}-2,60-62$ & 230.0 & 5.763 & 61.16 & 0.729 & 0.660 & 0.006 & 1.05 & 0.19 & 10.97 & 0.16 & 0.137 & 0.092 & 0.26 & 0.19 & 13.1 & 0.3 & 57.7 & 1.0 \\
\hline $22 \mathrm{H}-7,59-61$ & 238.8 & 5.873 & 61.16 & 0.729 & 0.630 & 0.002 & 1.14 & 0.19 & 9.60 & 0.22 & 0.129 & 0.041 & 0.51 & 0.17 & 12.0 & 0.3 & 52.9 & 1.3 \\
\hline $23 \times-5,0-150$ & 247.3 & 6.021 & 41.02 & 0.729 & 0.588 & 0.006 & 0.72 & 0.03 & 8.15 & 0.07 & 0.057 & 0.006 & 0.41 & 0.02 & 9.9 & 0.1 & 29.5 & 0.2 \\
\hline$-5,60-62$ & 247.5 & 6.025 & 41.02 & 0.729 & 0.592 & 0.03 & 1.40 & 0.21 & 6.30 & 0.02 & 0.082 & 0.015 & 0.54 & 0. & 8.9 & 0.2 & 26.4 & 0.6 \\
\hline & 255.6 & 6.201 & & 0.729 & 0.630 & 0.021 & 1.37 & 0.2 & 9.96 & 0.9 & 0.135 & 0.0 & 0.30 & 0 & 12.4 & 1.0 & 36.7 & 2.7 \\
\hline$x-1,60-62$ & 261.8 & 6.353 & 41.02 & 0.729 & 0.452 & 0.002 & 1.56 & 0.35 & 11.55 & 0.26 & 0.086 & 0.02 & 0.31 & 0.2 & 14.0 & 0.5 & 41.5 & 1.5 \\
\hline $27 \mathrm{X}-1,60-62$ & 281.3 & 7.093 & 37,92 & 0.706 & 0.696 & 0.033 & 1.44 & 0.34 & 7.11 & 0.23 & 0.104 & 0.005 & 0.39 & 0.41 & 9.7 & 0.6 & 25.8 & 1.6 \\
\hline$-6,58-60$ & 289.0 & 7.297 & 37. & 0.7 & 0.703 & 0.027 & 1.72 & 0.17 & 6.82 & 0.23 & 0.072 & 0.051 & 0.08 & 0.00 & 9.4 & 0.3 & 25.0 & 0.6 \\
\hline $3,60-62$ & 303.0 & 7.784 & 22. & 0.5 & 0.563 & 0.017 & 2.33 & 0.17 & 9.31 & 0.73 & 0.164 & 0.00 & 0.46 & 0. & 12.8 & 0.8 & 15.0 & 0.9 \\
\hline$-7,46-48$ & 308.5 & 7.985 & 22.76 & 0.5 & 0.577 & 0.040 & 2.53 & 0.07 & 12.08 & 0.24 & 0.224 & 0.159 & 0.25 & 0. & 15.7 & 0.3 & 18.2 & 0.2 \\
\hline$-2,60-62$ & 321.0 & 8.928 & 17.78 & 0.469 & 0.497 & 0.077 & 6.28 & 0.18 & 17.68 & 0.68 & 0.195 & 0.137 & 0.25 & 0.1 & 24.9 & 0.7 & 20.6 & 0.5 \\
\hline$-7,54-56$ & 327.9 & 9.281 & 16.80 & 0.449 & 0.342 & 0.03 & 6.78 & 0.4 & 9.73 & 0. & 0.216 & 0.15 & 0.36 & 0.4 & 17.4 & 0.9 & 13.0 & 0.5 \\
\hline & 335.0 & 9.773 & 14.50 & 0.383 & 0.154 & 0.03 & 6.29 & 0.01 & 2.59 & 0.12 & 0.471 & 0.3 & 0.37 & 0. & 9.9 & 0.4 & 5.2 & 0.0 \\
\hline$-3,61-63$ & 341.5 & 10.233 & 12. & 0.404 & 0.288 & 0.006 & 4.81 & 0.44 & 27.96 & 0.80 & 0.455 & 0.02 & 0.29 & 0. & 33.8 & 0.9 & 16.5 & 0.4 \\
\hline $\mathrm{x}-3,0-150$ & 341.7 & 10.245 & 12.2 & 0.4 & 0.334 & 0.003 & 4.40 & 0.75 & 21.09 & 0.95 & 0.228 & 0.0 & 0.87 & 0.02 & 26.9 & 1.2 & 13.2 & 0.6 \\
\hline$X-6,60-62$ & 355.7 & 11.129 & 17.20 & 0.663 & 0.460 & 0.024 & 1.78 & 0.15 & 16.08 & 0.31 & 0.143 & 0.070 & 0.60 & 0.28 & 19.1 & 0.5 & 21.6 & 0.4 \\
\hline $35 \times-4,57-59$ & 363.0 & 11.547 & 17.98 & 0.683 & 0.480 & 0.003 & 1.27 & 0.29 & 6.01 & 0.06 & 0.086 & 0.061 & 0.37 & 0.04 & 8.2 & 0.3 & 10.0 & 0.3 \\
\hline $36 \mathrm{X}-2,62-64$ & 369.6 & 11.915 & 17.98 & 0.683 & 0.385 & 0.008 & 1.48 & 0.37 & 15.86 & 2.21 & 0.122 & 0.041 & 0.47 & 0.2 & 18.3 & 2.2 & 22.3 & 2.7 \\
\hline $36 \times-7,44-46$ & 376.5 & 12.298 & 17.96 & 0.799 & 0.4 & 0.0 & 1.38 & 0.23 & 12.17 & 0.15 & 0.090 & 0.00 & 0.20 & 0.1 & 14.3 & 0.3 & 20.3 & 0.4 \\
\hline & 388.5 & 12.963 & 17. & 0.7 & 0.392 & 0.01 & 1.33 & 0. & 9.94 & 0.1 & 0.079 & 0.0 & 0.26 & 0. & 12.0 & 0.4 & 16.6 & 0.5 \\
\hline$x-1,60-62$ & 406.6 & 15.0 & 10. & 1.0 & 0.5 & 0.0 & 1.80 & 0.3 & 13.14 & 1.1 & 0.0 & 0.0 & 0.2 & 0. & 15.8 & 1.4 & 15.9 & 1.4 \\
\hline $41 X-1,58-60$ & 416.0 & 15.063 & 10.14 & 1.0 & 0.5 & $0.0 z$ & 1.62 & 0.06 & 16.34 & 0.35 & 0.050 & 0.035 & 0.22 & 0.2 & 18.8 & 0.4 & 19.0 & 0.4 \\
\hline $42 X-1,60-62$ & 425.7 & 16.018 & 10.14 & 1.000 & 0.383 & 0.017 & 1.57 & 0.27 & 23.35 & 0.55 & 0.086 & 0.061 & 0.44 & 0.00 & 25.8 & 0.6 & 26.1 & 0.6 \\
\hline $45 \times 01^{1}, 50-52$ & 453.9 & 18.000 & 10.14 & 1.000 & 0.137 & 0.016 & 4.64 & 0.03 & 164.53 & 0.02 & 5.046 & 0.848 & 0.32 & 0.10 & 174.7 & 0.9 & - & - \\
\hline
\end{tabular}

Note: For legend, see TAI. 
Table A3. Site 851.

\begin{tabular}{|c|c|c|c|c|c|c|c|c|c|c|c|c|c|c|c|c|c|c|}
\hline \multirow{2}{*}{$\begin{array}{l}\text { Core, section. } \\
\text { interval }(\mathrm{cm})\end{array}$} & \multirow{2}{*}{$\begin{array}{l}\text { Depth }^{a} \\
\text { (med) }\end{array}$} & \multirow{2}{*}{$\begin{array}{l}\text { Age }^{b} \\
(\mathrm{Ma})\end{array}$} & \multirow{2}{*}{$\begin{array}{l}\text { Sed. rt. } \\
(\mathrm{m} / \mathrm{m} . \mathrm{y} .)\end{array}$} & $\mathrm{DBD}^{\mathrm{d}}$ & Abse & orbed & Iron-t & und & Aut & 1./bio & De & rital & Orga & & Tota & & Tot & \\
\hline & & & & $\left(\mathrm{g} / \mathrm{cm}^{3}\right)$ & (P) & s.d. ${ }^{c}$ & (P) & s.d. & (P) & s.d. & (P) & s.d. & (P) & s.d. & (P) & s.d. & Pacc & s.d. \\
\hline |38-85|B- & & & & & & & & & & & & & & & & & & \\
\hline $1 \mathrm{H}-\mathrm{I}, 140-145$ & 0.6 & 0.028 & 17.78 & 0.59 & 1.595 & 0.003 & 1.86 & 0.14 & 5.16 & 0.20 & 0.094 & 0.001 & 0.71 & 0.04 & 9.4 & 0.2 & 9.9 & 0.3 \\
\hline IH-2, $140-145$ & 0.9 & 0.042 & 17.78 & 0.54 & 1.520 & 0.017 & 2.07 & 0.28 & 6.56 & 4.64 & 0.102 & - & 0.87 & 0.33 & 11.1 & 4.7 & 10.7 & 4.5 \\
\hline IH-3, 140-145 & 4.0 & 0.242 & 17.78 & 0.46 & 1.755 & 0.015 & 2.19 & 0.13 & 8.46 & 0.06 & 0.251 & 0.070 & 0.64 & 0.10 & 13.3 & 0.2 & 10.9 & 0.2 \\
\hline IH-4, 140-145 & 5.5 & 0.344 & 17.78 & 0.64 & 1.801 & 0.047 & 2.02 & 0.15 & 7.66 & 0.33 & 0.121 & 0.001 & 0.48 & 0.06 & 12.1 & 0.4 & 13.7 & 0.4 \\
\hline IH $-5,85-90$ & 7.1 & 0.430 & 17.78 & 0.63 & 2.143 & 0.037 & 2.20 & 0.11 & 5.25 & 0.17 & 0.106 & 0.007 & 0.50 & 0.11 & 10.2 & 0.2 & 11.4 & 0.3 \\
\hline $2 \mathrm{H}-1,140-144$ & 10.9 & 0.602 & 20.44 & 0.65 & 1.534 & 0.071 & 1.63 & 0.36 & 10.16 & 7.18 & bdl & - & 1.36 & - & 14.7 & 7.2 & 19.5 & 9.6 \\
\hline $2 \mathrm{H}-2,140-144$ & 12.5 & 0.643 & 20.44 & 0.64 & 1.831 & 0.024 & 1.76 & 0.13 & 6.47 & 0.21 & 0.139 & 0.028 & 0.50 & 0.00 & 10.7 & 0.2 & 14.0 & 0.3 \\
\hline $2 \mathrm{H}-3,140-144$ & 14.1 & 0.709 & 20.44 & 0.59 & 1.640 & 0.009 & 1.33 & 0.19 & 5.16 & 0.39 & 0.082 & - & 0.49 & 0.04 & 8.7 & 0.4 & 10.5 & 0.5 \\
\hline $2 \mathrm{H}-4,140-144$ & 15.4 & 0.790 & 20.44 & 0.63 & 1.480 & 0.014 & 1.28 & - & 7.40 & 0.45 & bdl & - & 0.70 & 0.34 & 10.9 & 0.6 & 14.0 & 0.7 \\
\hline $2 \mathrm{H}-5,140-144$ & 16.9 & 0.880 & 20.44 & 0.57 & 1.514 & 0.034 & 1.82 & 0.02 & 5.97 & 0.94 & 0.101 & - & 0.47 & 0.15 & 9.9 & 0.9 & 11.5 & 1.1 \\
\hline $2 \mathrm{H}-6,140-144$ & 18.5 & 0.960 & 20.44 & 0.56 & 1.425 & 0.002 & 1.44 & 0.31 & 6.48 & 4.58 & bdl & - & 0.67 & - & 10.0 & 4.6 & 11.5 & 5.3 \\
\hline $3 \mathrm{H}-1,140-144$ & 22.4 & 1.166 & 19.50 & 0.52 & 1.421 & 0.007 & 1.36 & 0.01 & 6.16 & 0.23 & 0.162 & 0.013 & 0.55 & 0.14 & 9.6 & 0.3 & 9.8 & 0.3 \\
\hline $3 \mathrm{H}-2,140-144$ & 23.7 & 1.247 & 19.50 & 0.58 & 1.592 & 0.018 & 1.71 & 0.07 & 4.78 & 0.11 & 0.105 & 0.047 & 0.40 & 0.10 & 8.6 & 0.2 & 9.7 & 0.2 \\
\hline $3 \mathrm{H}-3,140-144$ & 25.1 & 1.216 & 19.50 & 0.55 & 1.470 & 0.001 & 1.46 & 0.07 & 4.09 & 0.20 & 0.088 & 0.013 & 0.50 & 0.12 & 7.6 & 0.2 & 8.2 & 0.3 \\
\hline $3 \mathrm{H}-4,140-144$ & 26.8 & 1.394 & 19.50 & 0.55 & 1.335 & 0.030 & 1.48 & 0.03 & 6.98 & 4.93 & 0.183 & - & 0.64 & 0.30 & 10.6 & 4.9 & 11.4 & 5.3 \\
\hline $3 \mathrm{H}-5,140-144$ & 28.2 & 1.471 & 19.50 & 0.60 & 1.229 & 0.001 & 1.52 & 0.05 & 7.84 & 5.54 & 0.101 & - & 1.11 & 0.84 & 11.8 & 5.6 & 13.8 & 6.6 \\
\hline $3 \mathrm{H}-6,137-141$ & 29.6 & 1.533 & 15.76 & 0.52 & 1.243 & 0.008 & 1.76 & 0.04 & 9.29 & 0.20 & bdl & - & 0.78 & 0.19 & 13.1 & 0.3 & 10.7 & 0.2 \\
\hline $3 \mathrm{H}-7,37-4 \mathrm{I}$ & 30.8 & 1.630 & 15.76 & 0.57 & 1.262 & 0.018 & 1.55 & 0.05 & 11.23 & 0.48 & 0.203 & - & 1.34 & - & 15.6 & 0.5 & 14.0 & 0.4 \\
\hline $4 \mathrm{H}-1,140-145$ & 33.0 & 1.760 & 15.76 & 0.53 & 1.299 & 0.075 & 1.68 & 0.03 & 11.48 & 0.02 & 0.100 & 0.020 & 0.41 & 0.18 & 15.0 & 0.2 & 12.5 & 0.2 \\
\hline $4 \mathrm{H}-3,140-145$ & 35.3 & 1.910 & 15.76 & 0.37 & 1.140 & 0.044 & 1.32 & 0.06 & 12.28 & 0.18 & 0.126 & 0.028 & 0.55 & 0.13 & 15.4 & 0.2 & 9.0 & 0.1 \\
\hline $4 \mathrm{H}-5,140-145$ & 38.9 & 2.112 & 20.62 & 0.61 & 1.315 & 0.002 & 1.32 & 0.01 & 9.65 & 0.21 & 0.075 & 0.002 & 0.74 & 0.07 & 13.1 & 0.2 & 16.5 & 0.3 \\
\hline $5 \mathrm{H}-1,140-145$ & 43.3 & 2.345 & 20.62 & 0.55 & 1.262 & 0.010 & 1.38 & 0.03 & 10.49 & 0.33 & 0.116 & 0.035 & 0.58 & 0.01 & 13.8 & 0.3 & 15.7 & 0.4 \\
\hline $5 \mathrm{H}-3,140-145$ & 46.5 & 2.467 & 20.62 & 0.64 & 1.054 & 0.013 & 1.63 & 0.40 & 8.75 & 0.73 & 0.101 & - & 0.84 & 0.37 & 12.4 & 0.9 & 16.3 & 1.2 \\
\hline $5 \mathrm{H}-6,140-145$ & 50.8 & 2.723 & 19.10 & 0.62 & 1.357 & 0.013 & 1.40 & 0.02 & 7.50 & 0.34 & 0.083 & 0.013 & 0.51 & 0.21 & 10.8 & 0.4 & 12.8 & 0.5 \\
\hline $6 \mathrm{H}-1,140-145$ & 54.4 & 2.887 & 19.10 & 0.70 & 1.216 & 0.030 & 1.33 & 0.29 & 9.55 & 0.21 & 0.081 & - & 0.76 & 0.39 & 12.9 & 0.5 & 17.3 & 0.7 \\
\hline $6 \mathrm{H}-4,140-145$ & 58.9 & 3.123 & 19.08 & 0.47 & 1.181 & 0.007 & 1.67 & 0.13 & 11.17 & 0.60 & 0.122 & 0.013 & 0.47 & 0.05 & 14.6 & 0.6 & 13.1 & 0.5 \\
\hline $6 \mathrm{H}-6,139-144$ & 61.9 & 3.290 & 19.08 & 0.66 & 1.074 & 0.011 & 1.25 & 0.03 & 9.11 & 0.04 & 0.061 & - & 0.53 & 0.11 & 12.0 & 0.1 & 15.1 & 0.1 \\
\hline $7 \mathrm{H}-2,140-145$ & 66.0 & 3.488 & 19.08 & 0.70 & 1.311 & 0.001 & 1.59 & 0.15 & 8.83 & 0.27 & 0.082 & 0.025 & 0.33 & 0.05 & 12.1 & 0.3 & 16.2 & 0.4 \\
\hline $7 \mathrm{H}-4,140-145$ & 69.0 & 3.647 & 16.32 & 0.54 & 1.065 & 0.004 & 1.40 & 0.13 & 10.67 & 0.28 & 0.133 & 0.026 & 0.78 & 0.56 & 14.1 & 0.6 & 12.4 & 0.6 \\
\hline $8 \mathrm{H}-1,140-145$ & 75.4 & 4.084 & 19.98 & 0.64 & 1.218 & 0.025 & 1.39 & 0.06 & 11.13 & 0.05 & 0.083 & 0.011 & 0.51 & 0.07 & 14.3 & 0.1 & 18.3 & 0.1 \\
\hline $8 \mathrm{H}-3,140-145$ & 78.5 & 4.247 & 19.98 & 0.64 & 1.138 & 0.009 & 1.54 & 0.07 & 7.25 & 0.31 & bdl & - & 0.52 & - & 10.5 & 0.3 & 13.4 & 0.4 \\
\hline $8 \mathrm{H}-6,140-145$ & 82.9 & 4.446 & 19.98 & 0.81 & 1.259 & 0.031 & 1.43 & 0.04 & 8.04 & 0.15 & 0.074 & 0.007 & 0.52 & 0.15 & 11.3 & 0.2 & 18.3 & 0.4 \\
\hline $9 \mathrm{H}-1,140-144$ & 85.1 & 4.540 & 27.70 & 0.61 & 1.177 & 0.022 & 1.09 & 0.01 & 7.94 & 0.32 & 0.097 & 0.037 & 0.49 & 0.23 & 10.8 & 0.4 & 18.2 & 0.7 \\
\hline $9 \mathrm{H}-4,140-144$ & 89.9 & 4.713 & 27.70 & 0.70 & 1.130 & 0.006 & 0.96 & 0.18 & 8.67 & 0.53 & 0.089 & 0.025 & 0.34 & 0.02 & 11.2 & 0.6 & 21.7 & 1.1 \\
\hline $9 \mathrm{H}-6,140-144$ & 92.9 & 4.829 & 27.70 & 0.79 & 1.208 & 0.051 & 1.07 & 0.12 & 8.52 & 0.31 & 0.069 & 0.008 & 0.50 & 0.08 & 11.4 & 0.3 & 24.9 & 0.8 \\
\hline $10 \mathrm{H}-2,138-143$ & 98.0 & 4.994 & 27.70 & 0.74 & 1.056 & 0.000 & 0.82 & 0.19 & 6.74 & 0.49 & 0.082 & 0.002 & 0.26 & 0.02 & 9.0 & 0.5 & 18.4 & 1.1 \\
\hline $10 \mathrm{H}-4,140-145$ & 101.0 & 5.088 & 31.72 & 0.71 & 1.026 & 0.000 & 0.84 & 0.05 & 6.87 & 0.10 & 0.061 & 0.021 & 0.60 & 0.01 & 9.4 & 0.1 & 21.1 & 0.3 \\
\hline $10 \mathrm{H}-6,133-138$ & 104.0 & 5.212 & 31.72 & 0.69 & 0.871 & 0.027 & 0.80 & 0.16 & 7.94 & 0.63 & 0.051 & - & - & - & 9.7 & 0.6 & 21.1 & 1.4 \\
\hline $11 \mathrm{H}-2,140-145$ & 108.4 & 5.371 & 31.72 & 0.62 & 0.823 & 0.006 & 1.06 & 0.04 & 7.98 & 0.10 & 0.172 & - & - & - & 10.0 & 0.1 & 19.7 & 0.2 \\
\hline $12 \mathrm{H}-1,50-52$ & 118.6 & 5.595 & 41.56 & 0.72 & 0.919 & 0.004 & 2.30 & 0.10 & 7.28 & 0.27 & 0.523 & 0.370 & 0.62 & 0.12 & 11.6 & 0.5 & 34.8 & 1.4 \\
\hline $12 \mathrm{H}-6,50-52$ & 126.1 & 5.800 & 41.56 & 0.66 & 0.797 & 0.011 & 1.87 & 0.38 & 10.40 & 0.01 & bdl & - & 0.69 & 0.10 & 13.8 & 0.4 & 37.7 & 1.1 \\
\hline $13 \mathrm{H}-4,50-52$ & 133.4 & 5.955 & 41.56 & 0.81 & 0.854 & 0.005 & 2.03 & - & 7.37 & 0.05 & bdl & - & 0.67 & 0.06 & 10.9 & 0.1 & 36.8 & 0.3 \\
\hline $14 \mathrm{H}-2,50-52$ & 141.2 & 6.139 & 49.02 & 0.77 & 0.861 & 0.024 & 1.66 & 0.19 & 8.08 & 0.00 & bdl & - & 0.68 & 0.22 & 11.3 & 0.3 & 42.5 & 1.1 \\
\hline $14 \mathrm{H}-7,50-52$ & 148.6 & 6.246 & 49.02 & 0.73 & 0.780 & 0.003 & 1.41 & 0.47 & 9.78 & 1.05 & bdl & - & 0.74 & 0.08 & 12.7 & 1.2 & 45.5 & 4.1 \\
\hline $15 \mathrm{H}-5,50-52$ & 156.4 & 6.420 & 49.02 & 0.67 & 0.766 & 0.018 & 1.66 & - & 8.85 & 0.59 & bdl & - & 0.92 & 0.48 & 12.2 & 0.8 & 40.0 & 2.5 \\
\hline $16 \mathrm{X}-3,50-52$ & 163.1 & 6.611 & 53.94 & 0.62 & 0.687 & 0.007 & 1.39 & 0.09 & 10.79 & 0.70 & 0.125 & 0.029 & 0.63 & 0.03 & 13.6 & 0.7 & 45.6 & 2.4 \\
\hline $17 \times-2,50-52$ & 176.1 & 6.845 & 54.94 & 0.69 & 0.866 & 0.003 & 1.91 & 0.57 & 8.68 & - & 0.262 & 0.018 & 0.55 & 0.11 & 12.3 & 0.6 & 46.5 & 2.2 \\
\hline $17 X-7,50-52$ & 182.9 & 6.955 & 53.94 & 0.81 & 0.803 & 0.017 & 1.50 & 0.15 & 6.51 & 0.67 & bdl & - & 0.60 & 0.23 & 9.4 & 0.7 & 41.1 & 3.2 \\
\hline $18 \times-5,50-52$ & 195.3 & 7.175 & 42.85 & 0.74 & 0.860 & 0.019 & 2.26 & - & 5.95 & - & 0.318 & - & 0.61 & 0.08 & 10.0 & 0.1 & 31.7 & 0.3 \\
\hline $19 \times-4,49-51$ & 204.6 & 7.387 & 42.82 & 0.73 & 0.914 & 0.005 & 1.33 & 0.48 & 9.62 & 0.66 & 0.185 & 0.020 & 0.42 & 0.00 & 12.5 & 0.8 & 39.0 & 2.5 \\
\hline $20 \mathrm{X}-2,50-52$ & 217.1 & 7.705 & 41.52 & 0.62 & 0.754 & 0.014 & 0.95 & 0.16 & 9.51 & 6.72 & 0.112 & 0.072 & 0.54 & 0.07 & 11.9 & 6.7 & 30.5 & 17.3 \\
\hline $20 \times-7,47-49$ & 226.1 & 7.976 & 41.52 & 0.72 & 0.817 & 0.011 & 1.92 & 0.68 & 4.87 & 0.61 & bdl & - & 0.79 & 0.19 & 8.4 & 0.9 & 25.1 & 2.8 \\
\hline $21 X-5,52-54$ & 234.7 & 8.160 & 31.86 & 0.83 & 0.917 & 0.009 & 0.86 & 0.15 & 3.12 & 2.21 & bdl & - & 0.66 & 0.11 & 5.6 & 2.2 & 14.7 & 5.9 \\
\hline $22 \times-4,50-52$ & 242.4 & 8.437 & 31.86 & 0.91 & 0.832 & 0.006 & 1.01 & 0.00 & 10.57 & 0.32 & bdl & - & 0.71 & 0.19 & 13.1 & 0.4 & 38.0 & 1.1 \\
\hline $23 \mathrm{X}-3,50-52$ & 256.1 & 8.843 & 36.48 & 0.70 & 0.718 & 0.002 & 0.80 & 0.32 & 6.99 & 0.42 & 0.081 & - & 0.38 & 0.02 & 9.0 & 0.5 & 22.9 & 1.3 \\
\hline $24 X-2,50-52$ & 265.4 & 9.070 & 54.04 & 0.63 & 0.532 & 0.080 & 1.08 & 0.11 & 15.27 & 0.32 & bdl & - & 1.10 & 0.69 & 18.0 & 0.8 & 61.2 & 2.6 \\
\hline $24 X-7,50-52$ & 272.2 & 9.356 & 54.04 & 0.60 & 0.378 & 0.039 & 0.68 & 0.09 & 12.68 & 2.09 & 0.096 & 0.007 & 0.59 & 0.19 & 14.4 & 2.1 & 46.8 & 6.8 \\
\hline $25 X-5,50-52$ & 282.0 & 9.675 & 32.60 & 0.50 & 0.463 & 0.002 & 0.45 & - & 8.93 & 0.19 & bdl & - & 0.75 & 0.08 & 10.6 & 0.2 & 17.3 & 0.3 \\
\hline $26 \mathrm{X}-3,49-51$ & 292.9 & 10.010 & 44.68 & 0.58 & 0.390 & 0.010 & 0.82 & - & 12.48 & 0.60 & bdl & - & 0.95 & 0.09 & 14.6 & 0.6 & 37.9 & 1.6 \\
\hline $27 \mathrm{X}-2,49-51$ & 303.0 & 10.241 & 44.68 & 0.49 & 0.402 & 0.001 & 0.75 & 0.45 & 9.43 & 0.07 & bdl & - & 0.79 & 0.04 & 11.4 & 0.5 & 24.9 & 1.0 \\
\hline $27 X-7,54-56$ & 310.7 & 10.410 & 44.68 & 0.51 & 0.308 & 0.004 & 6.54 & 0.56 & 3.43 & 0.59 & bdl & - & 0.53 & 0.28 & 10.8 & 0.9 & 24.6 & 2.0 \\
\hline $28 X-5,50-52$ & 318.4 & 10.580 & 44.20 & 0.72 & 0.496 & 0.015 & 0.00 & - & 6.12 & 0.32 & bdl & - & 0.47 & 0.13 & 7.1 & 0.3 & 22.5 & 1.1 \\
\hline $29 X-3,50-52$ & 327.5 & 10.784 & 44.20 & 0.52 & 0.424 & 0.005 & 0.49 & 0.03 & 5.62 & 0.06 & bdl & - & 0.70 & 0.07 & 7.2 & 0.1 & 16.6 & 0.2 \\
\hline $31 \times-3,50-52$ & 346.4 & 11.222 & 37.96 & 0.85 & 0.581 & 0.000 & 0.73 & 0.02 & 7.50 & 0.34 & bdl & - & 0.57 & 0.09 & 9.4 & 0.3 & 30.2 & 1.1 \\
\hline $32 X-1,50-52$ & 354.9 & 11.467 & 37.96 & 0.93 & 0.507 & 0.003 & 0.73 & 0.25 & 8.99 & 0.95 & bdl & - & 0.57 & 0.12 & 10.8 & 1.0 & 38.1 & 3.5 \\
\hline $32 \times-6,50-52$ & 362.4 & 11.720 & 29.56 & 0.88 & 0.429 & 0.014 & 0.67 & 0.19 & 9.76 & 0.21 & 0.202 & - & 0.50 & 0.24 & 11.6 & 0.4 & 30.1 & 1.0 \\
\hline $33 X-5,50-52$ & 374.2 & 12.119 & 29.56 & 0.83 & 0.300 & 0.001 & 0.55 & - & 7.59 & 0.49 & 0.063 & 0.052 & 0.75 & 0.04 & 9.3 & 0.5 & 22.7 & 1.2 \\
\hline $34 X-3,50-52$ & 382.5 & 12.400 & 29.56 & 0.78 & 0.320 & & - & 0.47 & - & 13.57 & - & bdl & - & 0.65 & - & 15.0 & 0.0 & 34.6 \\
\hline
\end{tabular}

Note: For legend, see TAI. 